
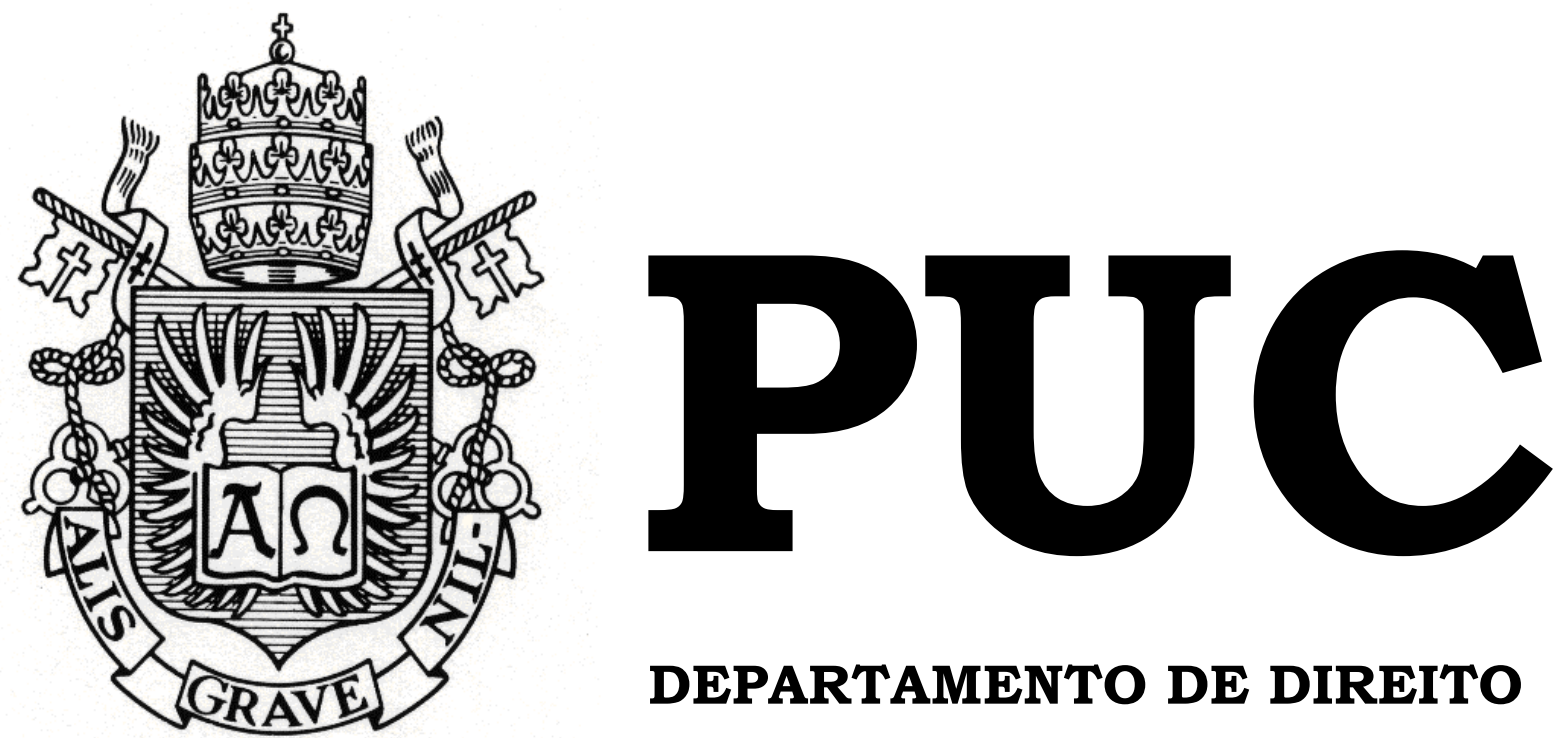

DEPARTAMENTO DE DIREITO

\title{
A Correlação entre o Dever de Diligência dos Administradores e o Interesse Público das Sociedades de Economia Mista
}

por

Frederico Antonio Menescal Conde Rocha

ORIENTADOR(A): Francisco Antunes Maciel Müssnich

2015.1

PONTIFÍCIA UNIVERSIDADE CATÓLICA DO RIO DE JANEIRO

RUA MARQUÊS DE SÃO VICENTE, 225 - CEP 22453-900

$$
\text { RIO DE JANEIRO - BRASIL }
$$




\title{
A Correlação entre o Dever de Diligência dos Administradores e o Interesse Público das Sociedades de Economia Mista
}

\author{
por \\ Frederico Antonio Menescal Conde Rocha \\ Monografia apresentada ao \\ Departamento de Direito da Pontificia \\ Universidade Católica do Rio de \\ Janeiro (PUC-Rio) para a obtenção do \\ Título de Bacharel em Direito.
}

Orientador(a): Francisco Antunes Maciel Müssnich

2015.1 
Dedicatória

Aos meus pais e irmã, obrigado por tudo. 


\section{Agradecimentos}

Primeiramente, agradeço aos meus amados pais, Tannit e Renato, pelo infinito amor, carinho, apoio, motivação e ensinamentos ao longo de toda minha vida, bem como pelo exemplo e educação que me proporcionaram.

Agradeço à minha irmã Rafaela por estar sempre ao meu lado e pelo amor, carinho e compreensão incondicionais.

Agradeço ao Professor Francisco Müssnich pela honra de ser meu orientador neste trabalho.

Agradeço aos meus companheiros de BMA, principalmente à Carla Vilmar da Motta Veiga, à Anna Carolina Malta e ao Conrado Chaves pelo excelente convívio diário, me proporcionando um constante crescimento tanto profissional quanto pessoal. Agradeço também ao Fábio Henrique Peres, quem me deu relevante ajuda no desenvolvimento do tema desta monografia.

Por fim, agradeço ao restante da minha família e aos amigos que também contribuíram para o meu crescimento e formação, enumerá-los aqui seria tarefa injusta, uma vez que a todos nunca seria possível contemplar.

Frederico Antonio Menescal Conde Rocha 


\section{Epígrafe}

“O correr da vida embrulha tudo.

A vida é assim: esquenta e esfria, aperta e daí afrouxa, sossega e depois desinquieta.

O que ela quer da gente é coragem.”

Guimarães Rosa 


\section{Resumo}

O presente trabalho monográfico se propõe, primeiramente, a analisar a estrutura organizacional de uma companhia, com foco específico nos Órgãos de Administração compostos pela Diretoria e pelo Conselho de Administração.

Em seguida, serão analisados o papel e a importância dos Administradores - diretores e conselheiros - de uma companhia, abordando seus principais deveres e responsabilidades. Dentre os deveres dos Administradores, será examinado o dever de diligência e seus desdobramentos, incluindo ainda a business judgment rule.

Posteriormente, será estudado o regime jurídico das sociedades de economia mista e o interesse público que justifica a sua criação.

Por fim, por meio do exposto ao longo do trabalho, será realizada uma correlação entre o dever de diligência dos administradores e o interesse público que rege as sociedades de economia mista.

\section{Palavras-Chave:}

Companhia - Órgãos de Administração - Diretoria - Conselho de Administração - Administradores - Dever de Diligência - Sociedades de Economia Mista - Interesse Público - Correlação 


\section{Sumário}

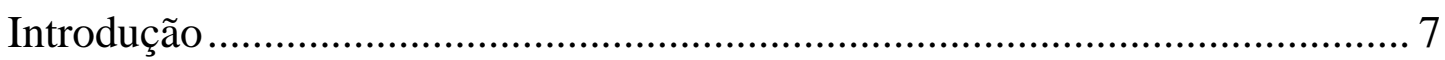

CAPÍTULO 1. DA ESTRUTURA ORGANIZACIONAL DE UMA

COMPANHIA …………...................................................................... 9

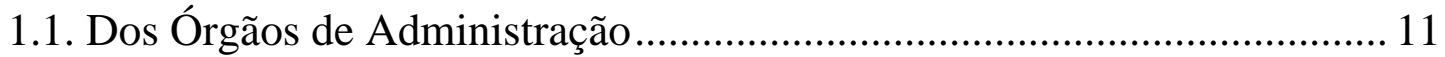

1.1.1. O Conselho de Administração................................................................. 11

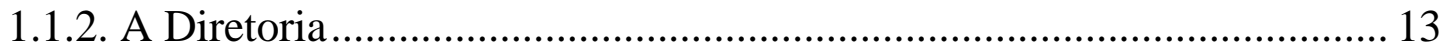

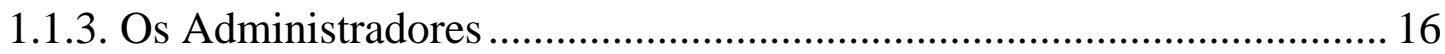

CAPÍTULO 2. DOS DEVERES DOS ADMINISTRADORES ........................ 19

2.1. Dever de Diligência ..................................................................................... 23

2.2. Dos Deveres Abarcados no Dever de Diligência e da Business

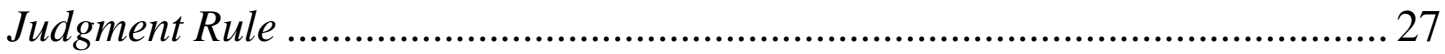

2.2.1. Dever de se Qualificar para o Cargo ..................................................... 27

2.2.2. Dever de Bem Administrar................................................................... 27

2.2.3. Dever de se Informar ........................................................................... 28

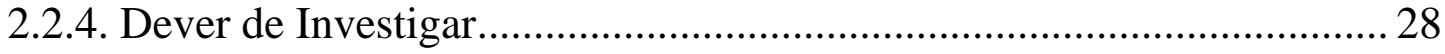

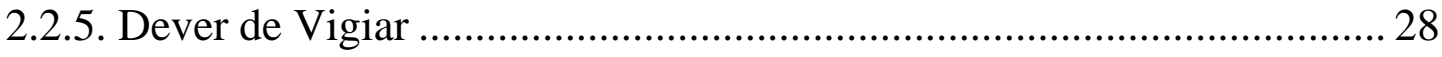

2.2.6. Business Judgment Rule …………………………................................ 29

Capítulo 3. DAS SOCIEDADES DE ECONOMIA MISTA ............................... 31

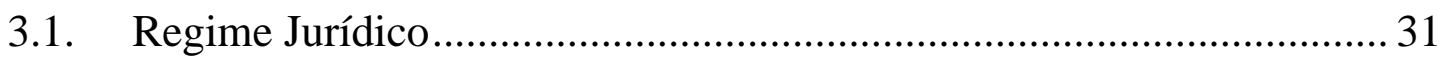

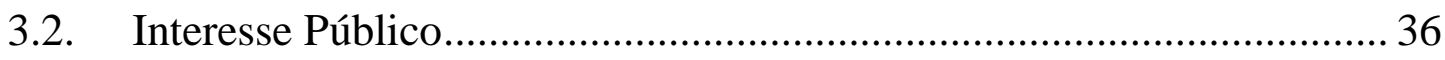

CAPÍTULO 4. POSICIONAMENTOS CVM ………………………….......... 41

4.1. Caso Sadia S.A. (PAS CVM no 18/08) - Dever de Diligência ............... 41

4.2. Caso Centrais Elétricas Brasileiras S.A. - Eletrobras

(PAS CVM nº RJ2013/6635) - Interesse Público ............................................... 43

CAPÍTULO 5. CORRELAÇÃO ENTRE O DEVER DE DILIGÊNCIA

DOS ADMINISTRADORES E O INTERESSE PÚBLICO DAS

SOCIEDADES DE ECONOMIA MISTA

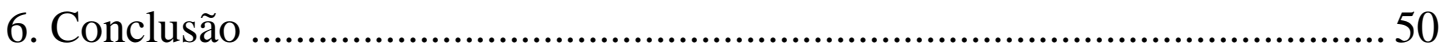

7. Referências Bibliográficas........................................................................... 52 


\section{Introdução}

A estrutura organizacional de uma companhia necessariamente compõe-se da Assembleia Geral, da Diretoria e do Conselho Fiscal, e o Conselho de Administração a integra como órgão facultativo, salvo nas companhias abertas, nas de capital autorizado e nas sociedades de economia mista, em que será órgão obrigatório.

A Diretoria e o Conselho de Administração juntos constituem os Órgãos de Administração, cujos membros - respectivamente, os diretores e os conselheiros - são os Administradores, que têm uma série de deveres e responsabilidades no desempenho de suas funções.

Dentre estes deveres dos Administradores se destaca o dever de diligência, positivado no artigo 153 da Lei nº 6.404/76, estabelecendo um comportamento, um padrão de conduta, que se caracteriza como a regra suprema no norte de atuação dos Administradores de uma companhia.

A sociedade de economia mista, pela definição dada pelo DecretoLei $n^{\circ}$ 200/1967, em seu artigo 5, III, trata-se de uma "entidade dotada de personalidade jurídica de direito privado, criada por lei para a exploração de atividade econômica, sob a forma de sociedade anônima, cujas ações com direito a voto pertençam em sua maioria à União ou a entidade da Administração Indireta.”

Constituindo um dos principais instrumentos utilizados pelo Estado para intervir como empresário no domínio econômico, a sociedade de economia mista, somente poderá explorar os empreendimentos ou exercer as atividades previstas na lei que autorizou a sua constituição ${ }^{1}$ que tem como justificativa atender a um interesse público.

\footnotetext{
${ }^{1}$ De acordo com o artigo 237 da Lei $\mathrm{n}^{\mathrm{o}}$ 6.404/76, “A companhia de economia mista somente poderá explorar os empreendimentos ou exercer as atividades previstas na lei que autorizou a sua constituição."
} 
Portanto, como a sociedade de economia mista tem um interesse público que justificou a sua constituição, é de suma importância refletir acerca do desempenho do dever de diligência por parte de seus Administradores.

Ao longo do presente trabalho será analisado cada um dos pontos mencionados acima, para que possamos ao fim traçarmos uma correlação entre o dever de diligência dos Administradores e o interesse público das sociedades de economia mista. 


\section{CAPÍTULO 1. DA ESTRUTURA ORGANIZACIONAL DE UMA COMPANHIA}

A Lei $n^{\circ}$ 6.404, de 15 de dezembro de 1976 (a “Lei no 6.404/76”), dispõe sobre as sociedades por ações e estabelece que toda companhia deve ter necessariamente três órgãos: a Assembleia Geral, a Diretoria e o Conselho Fiscal. O Conselho de Administração constitui órgão obrigatório nas companhias abertas, de capital autorizado $^{2}$ e sociedades de economia mista $^{3}$, com exceção dessas três hipóteses constitui em órgão facultativo da companhia ${ }^{4}$.

A Assembleia Geral é o órgão social da companhia, sendo nada mais, nada menos, que uma reunião dos seus acionistas, regularmente convocada e instalada ${ }^{5}$; o Conselho de Administração e a Diretoria compõem os órgãos de administração da companhia; e o Conselho Fiscal, por sua vez, tem a função de fiscalizar os atos dos administradores, e opinar sobre propostas destes que serão submetidas à deliberação dos acionistas em Assembleia Geral ${ }^{6}$.

As atribuições de cada um desses órgãos da companhia são definidas pela Lei $\mathrm{n}^{\circ}$ 6.404/76: (i) o artigo $122^{7}$ enumera os atos que são de

\footnotetext{
${ }^{2}$ De acordo com o $\S 2^{\circ}$ do artigo 138 da Lei ${ }^{\circ}$ 6.404/76, "As companhias abertas e as de capital autorizado terão, obrigatoriamente, conselho de administração.”

${ }^{3}$ De acordo com o artigo 239 da Lei $\mathrm{n}^{\circ}$ 6.404/76, "As companhias de economia mista terão obrigatoriamente Conselho de Administração, assegurado à minoria o direito de eleger um dos conselheiros, se maior número não lhes couber pelo processo de voto múltiplo.”

${ }^{4}$ PEDREIRA, José Luiz Bulhões; FILHO, Alfredo Lamy, Direito das Companhias, Volume I, Rio de Janeiro: Editora Forense, 2009, p. 802.

${ }^{5}$ CASTELLO BRANCO, Adriano, O Conselho de Administração nas Sociedades Anônimas, Rio de Janeiro: Forense Universitária, 2007, p. 29

${ }^{6}$ PEDREIRA, José Luiz Bulhões; FILHO, Alfredo Lamy, 2009a, p. 802 e ss.

${ }^{7}$ De acordo com o art. 122 da Lei no ${ }^{\circ}$ 6.404/76, "Compete privativamente à assembleia geral: I reformar o estatuto social; II - eleger ou destituir, a qualquer tempo, os administradores e fiscais da companhia, ressalvado o disposto no inciso II do art. 142; III - tomar, anualmente, as contas dos administradores e deliberar sobre as demonstrações financeiras por eles apresentadas; IV autorizar a emissão de debêntures, ressalvado o disposto no § 1o do art. 59; IV - autorizar a emissão de debêntures, ressalvado o disposto nos $\S \S 10$, 20 e 40 do art. 59; V - suspender o exercício dos direitos do acionista (art. 120); VI - deliberar sobre a avaliação de bens com que o acionista concorrer para a formação do capital social; VII - autorizar a emissão de partes beneficiárias; VIII - deliberar sobre transformação, fusão, incorporação e cisão da companhia, sua
} 
competência privativa da Assembleia Geral; (ii) o Conselho de Administração é órgão de deliberação colegiada ${ }^{8}$, e os atos de sua competência estão elencados no artigo 1429\% (iii) os diretores têm a competência privativa de representação da companhia ${ }^{10}$, admitindo a Lei ${ }^{\circ}$ 6.404/76 que o estatuto e o Conselho de Administração (observado o que a respeito dispuser o estatuto social) fixem as suas atribuições ${ }^{11}$; e (iv) o artigo $163^{12}$ dispõe acerca das atribuições de competência do Conselho Fiscal $^{13}$.

Dentre estes órgãos, a Diretoria é o único que tem funcionamento permanente, enquanto que a Assembleia Geral se reúne obrigatoriamente

dissolução e liquidação, eleger e destituir liquidantes e julgar-lhes as contas; e IX - autorizar os administradores a confessar falência e pedir concordata.”

${ }^{8}$ De acordo com o $\$ 1^{\circ}$ da Lei $n^{\circ}$ 6.404/76, “O conselho de administração é órgão de deliberação colegiada, sendo a representação da companhia privativa dos diretores.”

${ }^{9}$ De acordo com o art. 142 da Lei $n^{\circ}$ 6.404/76, "Compete ao conselho de administração: I - fixar a orientação geral dos negócios da companhia; II - eleger e destituir os diretores da companhia e fixar-lhes as atribuições, observado o que a respeito dispuser o estatuto; III -fiscalizar a gestão dos diretores, examinar, a qualquer tempo, os livros e papéis da companhia, solicitar informações sobre contratos celebrados ou em via de celebração, e quaisquer outros atos; IV - convocar a assembleia geral quando julgar conveniente, ou no caso do artigo 132; V - manifestar-se sobre o relatório da administração e as contas da diretoria; VI - manifestar-se previamente sobre atos ou contratos, quando o estatuto assim o exigir; VII - deliberar, quando autorizado pelo estatuto, sobre a emissão de ações ou de bônus de subscrição; VIII - autorizar, se o estatuto não dispuser em contrário, a alienação de bens do ativo não circulante, a constituição de ônus reais e a prestação de garantias a obrigações de terceiros; e IX - escolher e destituir os auditores independentes, se houver."

${ }^{10}$ De acordo com o $\S 1^{\circ}$ da Lei $n^{\circ} 6.404 / 76$, “O conselho de administração é órgão de deliberação colegiada, sendo a representação da companhia privativa dos diretores.”

${ }^{11}$ De acordo com o art. 144 da Lei $n^{\circ}$ 6.404/76, "No silêncio do estatuto e inexistindo deliberação do conselho de administração (artigo 142, n. II e parágrafo único), competirão a qualquer diretor a representação da companhia e a prática dos atos necessários ao seu funcionamento regular.”

${ }^{12}$ De acordo com o art. 163 da Lei $n^{\circ}$ 6.404/76, "Compete ao conselho fiscal: I - fiscalizar, por qualquer de seus membros, os atos dos administradores e verificar o cumprimento dos seus deveres legais e estatutários; II - opinar sobre o relatório anual da administração, fazendo constar do seu parecer as informações complementares que julgar necessárias ou úteis à deliberação da assembleia geral; III - opinar sobre as propostas dos órgãos da administração, a serem submetidas à assembleia geral, relativas a modificação do capital social, emissão de debêntures ou bônus de subscrição, planos de investimento ou orçamentos de capital, distribuição de dividendos, transformação, incorporação, fusão ou cisão; IV - denunciar, por qualquer de seus membros, aos órgãos de administração e, se estes não tomarem as providências necessárias para a proteção dos interesses da companhia, à assembleia geral, os erros, fraudes ou crimes que descobrirem, e sugerir providências úteis à companhia; V - convocar a assembleia geral ordinária, se os órgãos da administração retardarem por mais de 1 (um) mês essa convocação, e a extraordinária, sempre que ocorrerem motivos graves ou urgentes, incluindo na agenda das assembleias as matérias que considerarem necessárias; VI - analisar, ao menos trimestralmente, o balancete e demais demonstrações financeiras elaboradas periodicamente pela companhia; VII - examinar as demonstrações financeiras do exercício social e sobre elas opinar; e VIII - exercer essas atribuições, durante a liquidação, tendo em vista as disposições especiais que a regulam.”

${ }^{13}$ PEDREIRA, José Luiz Bulhões; FILHO, Alfredo Lamy,2009a, p. 803. 
apenas uma vez por ano, dentro de quatro meses após o encerramento do exercício social (Assembleia Geral Ordinária), podendo reunir-se extraordinariamente quando convocada nos termos da Lei $\mathrm{n}^{\circ}$ 6.404/76 (Assembleia Geral Extraordinária); o Conselho de Administração funciona durante reuniões ordinárias, cuja periodicidade deve ser fixada no estatuto social, ou em reuniões extraordinárias; e o Conselho Fiscal, como for estabelecido no estatuto, pode ser instalado somente quando solicitado pelos acionistas e, quando instalado, deve reunir-se ao menos uma vez por trimestre, para realização de análises acerca do balancete e demais demonstrações financeiras elaboradas pela companhia ${ }^{14}$.

Além dos órgãos previstos, a Lei ${ }^{0}$ 6.404/76, admite também, em seu artigo $160^{15}$, que o estatuto possa criar outros órgãos com funções técnicas, ou destinados a aconselhar os Administradores, cujos membros terão os mesmos deveres e responsabilidades destes. Tal dispositivo é mais usualmente utilizado para criar "Conselhos Consultivos" com o objetivo de opinar sobre determinados assuntos, a pedido dos órgãos de administração ou nos casos previstos no estatuto da companhia. ${ }^{16}$

\subsection{Dos Órgãos de Administração}

\subsubsection{O Conselho de Administração}

O Conselho de Administração, que se encontra em uma posição intermediária entre a Assembleia Geral e a Diretoria, constitui órgão integrante da estrutura da administração de uma companhia. É o órgão de maior importância na vida social de uma companhia, uma vez que lhe compete exercer funções deliberativas - as quais vão desde a escolha de

\footnotetext{
${ }^{14}$ PEDREIRA, José Luiz Bulhões; FILHO, Alfredo Lamy, 2009a, p. 804.

${ }^{15}$ De acordo com o artigo 160 da Lei $\mathrm{n}^{\circ}$ 6.404/76, "As normas desta Seção aplicam-se aos membros de quaisquer órgãos, criados pelo estatuto, com funções técnicas ou destinados a aconselhar os administradores."

${ }^{16}$ PEDREIRA, José Luiz Bulhões; FILHO, Alfredo Lamy. Op.cit..
} 
diretores até a orientação geral dos negócios da companhia - e de ordenação interna. ${ }^{17}$

Neste contexto, eis a lição de Cesare Vivante:

"O conselho é o órgão permanente da administração social, que, salvas as restrições escritas nos estatutos, pode realizar todas as operações sociais; pois que, tanto no sistema da lei, como na prática, a assembleia dos sócios não é um órgão administrativo apropriado para deliberar sobre cada uma das operações: a lentidão, a publicidade das suas reuniões, a isso se opõem; a ocasião oportuna para o negócio teria passado e tornado a passar quando chegasse à deliberação da assembleia."18

A Lei $n^{\circ}$ 6.404/76 atribui ao Conselho de Administração algumas competências que originalmente foram conferidas à Assembleia Geral com intuito de se obter um funcionamento mais ágil da companhia. Caberá ao Conselho de Administração deliberar acerca de qualquer assunto de interesse social, salvo os que são de competência privativa da Assembleia Geral ou do Conselho Fiscal, se em funcionamento. ${ }^{19}$

Devido à evolução dos negócios, na medida em que a empresa necessitou tomar medidas mais complexas, houve uma progressiva transferência de poderes da Assembleia Geral para o Conselho de Administração. Dando, assim, maior liberdade ao Conselho de Administração à sua atuação dentro da esfera societária. ${ }^{20}$

O Código das Melhores Práticas de Governança Corporativa, editado pelo Instituto Brasileiro de Governança Corporativa, deu uma interessante definição à “missão” do Conselho de Administração:

“A missão do Conselho de Administração é proteger e valorizar a organização, otimizar o retorno do investimento no longo prazo e buscar o equilíbrio entre os

\footnotetext{
${ }^{17}$ CASTELLO BRANCO, Adriano, Op. cit,. p. 29

${ }^{18}$ VIVANTE, Cesare, Instituições de Direito Comercial; Tradução e notas de Ricardo Rodrigues Gama, Campinas - SP: LZN Editora, 2003, p..110.

${ }^{19}$ PARENTE, Flavia. O Dever de Diligência dos Administradores de Sociedades Anônimas. Rio de Janeiro: Renovar, 2005. p.. 7.

${ }^{20}$ WALD, Arnoldo. Do Regime Legal do Conselho de Administração e da Liberdade de Votos dos seus Componentes. Revista da Associação dos Juízes do Rio Grande do Sul - Ajuris, n. 43.p. 177.
} 
anseios das partes interessadas (shareholders ${ }^{21}$ e demais stakeholders ${ }^{22}$ ), de modo que cada uma receba benefício apropriado e proporcional ao vínculo que possui com a organização e ao risco a que está exposta ${ }^{23}$.”

Conforme definido no artigo 138 da Lei n ${ }^{\circ}$ 6.404/76, o Conselho de Administração é órgão de deliberação colegiada, o que significa que seus membros - os conselheiros - não têm competência individual e, por isso, singularmente não podem exercer qualquer atribuição, e sim, somente em conjunto. As decisões do Conselho de Administração, manifestações de sua vontade, são tomadas em reuniões, mediante votação, caso seja necessário, sempre prevalecendo o princípio majoritário, este que é princípio basilar da Lei ${ }^{0}$ 6.404/76. As decisões tomadas pelo Conselho de Administração vinculam todos os seus membros, mesmo os ausentes e os dissidentes, que poderão lavrar seus votos em separado ${ }^{24}$.

\subsubsection{A Diretoria}

A Diretoria é o órgão de representação legal da companhia e de execução das deliberações da Assembleia Geral e do Conselho de Administração ${ }^{25}$, sendo suas atribuições executivas, exclusivas e indelegáveis ${ }^{26}$. Em regra, a Diretoria não é órgão colegiado, podendo cada um de seus membros atuar individualmente dentro de suas respectivas atribuições.

Seus membros, os diretores (pessoas naturais, residentes no País, acionistas ou não), são os únicos que representam a companhia perante

\footnotetext{
${ }^{21}$ Detentor de ações ou quotas de determinada organização.

22 Qualquer pessoa, entidade ou sistema que afeta ou é afetada(o) pelas atividades de uma organização. Partes interessadas.

23 INSTITUTO BRASILEIRO DE GOVERNANÇA CORPORATIVA. Código das Melhores Práticas de Governança Corporativa, 4a edição. São Paulo, SP: IBGC, 2009. Disponível em http://www.ibgc.org.br. Acesso em 23 de maio de 2015.

${ }^{24}$ EIZIRIK, Nelson. A Lei das S/A Comentada. Volume II - Arts. 121 a 188. São Paulo: Editora Quartier Latin, 2011, p. 261.

${ }^{25}$ PARENTE, Flávia. Op. cit., p. 15.

${ }^{26}$ CASTELLO BRANCO, Adriano, Op. cit,. p. 29.
} 
terceiros $^{27}$, ou seja, compete aos diretores a gestão ordinária dos negócios sociais $^{28}$ no plano interno e, com relação ao plano externo, manifestam a vontade da companhia ${ }^{29}$.

A Diretoria deverá ser composta por pelo menos 2 (dois) diretores, eleitos e destituíveis a qualquer tempo pelo Conselho de Administração, ou caso este não exista, pela Assembleia Geral. O estatuto social deverá estabelecer sua composição, prazo de gestão e modo de substituição dos diretores, atribuições e poderes de cada diretor e seu funcionamento. ${ }^{30}$

Na eleição realizada pelo Conselho de Administração, a deliberação obedecerá ao que dispuser o estatuto social da companhia e, na eleição pela Assembleia Geral. Se o estatuto social for omisso quanto ao processo de votação, caberá à própria Assembleia Geral estabelecê-lo por proposta da mesa ou de acionista ${ }^{31}$.

Na hipótese de eleição dos diretores por meio da Assembleia Geral, o acionista minoritário não terá direito ao processo de voto múltiplo ${ }^{32}$, sendo este cabível apenas para a eleição de conselheiros por ser o Conselho de Administração o órgão de maior responsabilidade quanto à direção dos negócios sociais da companhia. Neste sentido, explica Nelson Eizirik:

\footnotetext{
“O Projeto de Lei que resultou na Lei no 10.303/2001 havia previsto nova redação ao caput, mediante a qual deveria ser utilizado o voto múltiplo quando a eleição dos diretores fosse feita pela Assembleia Geral. A alteração foi vetada, sob o fundamento de não ser o voto múltiplo compatível com a natureza da diretoria, à qual cabe a função executiva, com responsabilidades concretas para implementar o objeto da companhia, diversamente do que ocorre com Conselho de

${ }^{27}$ PEDREIRA, José Luiz Bulhões; FILHO, Alfredo Lamy, 2009a, p. 802.

${ }^{28}$ EIZIRIK, Nelson, 2011a., p. 297.

${ }^{29}$ PARENTE, Flávia. Op. cit., p. 15.

${ }^{30}$ De acordo com o artigo 143 da Lei no 6.404/76, “A Diretoria será composta por 2 (dois) ou mais diretores, eleitos e destituíveis a qualquer tempo pelo conselho de administração, ou, se inexistente, pela assembleia geral, devendo o estatuto estabelecer: I - o número de diretores, ou o máximo e o mínimo permitidos; II - o modo de sua substituição; III - o prazo de gestão, que não será superior a 3 (três) anos, permitida a reeleição; IV - as atribuições e poderes de cada diretor. § $1^{\circ}$ Os membros do conselho de administração, até o máximo de 1/3 (um terço), poderão ser eleitos para cargos de diretores. $\S 2^{\circ} \mathrm{O}$ estatuto pode estabelecer que determinadas decisões, de competência dos diretores, sejam tomadas em reunião da diretoria."

${ }^{31}$ SOUZA LEÃO JR., Luciano de in PEDREIRA, José Luiz Bulhões; FILHO, Alfredo Lamy, 2009a, p. 1.062.

${ }^{32}$ EIZIRIK, Nelson. 2011a, p 300.
} 
Administração, que constitui órgão de deliberação colegiada e de formulação das políticas gerais da companhia.,33

Com intuito de manter a dualidade de órgãos de administração ${ }^{34}$, a Lei $n^{0}$ 6.404/76, admite somente a cumulação de cargo de diretor com o de conselheiro até o máximo de 1/3 (um terço) do número de membros do Conselho de Administração ${ }^{35}$.

A representação legal da companhia é de competência privativa dos diretores ${ }^{36}$, não podendo ser atribuída a qualquer outro órgão da sociedade. Trata-se da chamada representação orgânica, expressão usada para distingui-la da representação propriamente dita, que pode ser legal (caso do tutor, curador, inventariante ou síndico de massa falida) ou convencional (procurador ou mandatário) $^{37}$. A atribuição da representação legal compete ao diretor que a tenha recebido pelo estatuto social, ou, no silêncio deste, por deliberação do Conselho de Administração. Na ausência de designação no estatuto e de deliberação do Conselho de Administração, a representação da companhia competirá a qualquer dos diretores ${ }^{38}$.

Os poderes dos diretores são indelegáveis, porém poderão constituir mandatários da companhia, devendo o instrumento de mandato especificar os atos ou operações que os procuradores poderão praticar, assim como a duração do mandato, que, se judicial, poderá ser por prazo indeterminado ${ }^{39}$.

\footnotetext{
${ }^{33}$ EIZIRIK, Nelson. 2011a, p 300.

${ }^{34}$ PEDREIRA, José Luiz Bulhões; FILHO, Alfredo Lamy, 2009a, p. 1063.

35 De acordo com $\S 1^{\circ}$ do artigo 143 da Lei ${ }^{\circ}$ 6.404/76, "Os membros do conselho de administração, até o máximo de 1/3 (um terço), poderão ser eleitos para cargos de diretores.”

${ }^{36}$ De acordo com $\$ 1^{\circ}$ do artigo 138 da Lei n ${ }^{\circ} 6.404 / 76$, "O conselho de administração é órgão de deliberação colegiada, sendo a representação da companhia privativa dos diretores."

${ }^{37}$ SOUZA LEÃO JR., Luciano de in PEDREIRA, José Luiz Bulhões; FILHO, Alfredo Lamy, 2009a, p. 1065.

${ }^{38}$ De acordo com o artigo 144 da Lei $\mathrm{n}^{\circ}$ 6.404/76, "No silêncio do estatuto e inexistindo deliberação do conselho de administração (artigo 142, n. II e parágrafo único), competirão a qualquer diretor a representação da companhia e a prática dos atos necessários ao seu funcionamento regular."

${ }^{39}$ De acordo com o parágrafo único do artigo 144 da Lei ${ }^{\circ}$ 6.404/76, "Nos limites de suas atribuições e poderes, é lícito aos diretores constituir mandatários da companhia, devendo ser especificados no instrumento os atos ou operações que poderão praticar e a duração do mandato, que, no caso de mandato judicial, poderá ser por prazo indeterminado.”
} 
Dessa forma, os diretores estão investidos dos poderes de gestão ${ }^{40} \mathrm{e}$ de representação ${ }^{41}$, no sentido de que o poder de gestão, uma vez compartilhado com o Conselho de Administração, se existente, significa o poder de deliberar e decidir a respeito dos negócios sociais da companhia ${ }^{42}$, enquanto que o poder de representação equivale ao poder de manifestar a vontade social externamente, em relação a terceiros ${ }^{43}$.

\subsubsection{Os Administradores}

Nas palavras de José Xavier Carvalho de Mendonça: “Os administradores são órgãos permanentes da sociedade; são os gestores do patrimônio social." ${ }^{44}$

Em seu artigo $145^{45}$, a Lei $n^{0} 6.404 / 76$ se refere aos membros do Conselho de Administração e Diretoria - conselheiros e diretores, respectivamente - como Administradores, estabelecendo um princípio de igualdade entre eles ${ }^{46}$, sendo-lhes aplicáveis as normas relacionadas aos requisitos, impedimentos, investidura, remuneração, deveres e responsabilidades.

A Lei $\mathrm{n}^{\circ}$ 6.404/76 estabelece o requisito de que somente pessoas naturais poderão ser eleitas para membros dos Órgãos de Administração, devendo os diretores serem residentes no País ${ }^{47}$. Porém, em contrapartida,

\footnotetext{
${ }^{40}$ De acordo com o artigo 138 da Lei ${ }^{\circ}$ 6.404/76, “A administração da companhia competirá, conforme dispuser o estatuto, ao conselho de administração e à diretoria, ou somente à diretoria."

${ }^{41}$ De acordo com $\S 1^{\circ}$ do artigo 138 da Lei no 6.404/76, "O conselho de administração é órgão de deliberação colegiada, sendo a representação da companhia privativa dos diretores."

${ }^{42}$ SOUZA LEÃO JR., Luciano de in PEDREIRA, José Luiz Bulhões; FILHO, Alfredo Lamy, 2009a, p.1065.

${ }^{43}$ CARVAlHOSA, Modesto. Comentários à Lei das Sociedades Anônimas. $3^{\circ}$ Volume. Artigos 138 a 205. $4^{a}$ ed.São Paulo: Saraiva, 2009, p. 175.

${ }^{44}$ CARVALHO DE MENDONÇA, José Xavier. Tratado de Direito Comercial Brasileiro, Volume IV, Livro II Dos Comerciantes e seus Auxiliares, Parte III - Das Sociedades Comerciais, $5^{\mathrm{a}}$ edição. São Paulo: Livraria Freitas Bastos S.A., 1954, p. 38.

45 De acordo com o artigo 145 da Lei $\mathrm{n}^{\circ}$ 6.404/76, “As normas relativas a requisitos, impedimentos, investidura, remuneração, deveres e responsabilidade dos administradores aplicam-se a conselheiros e diretores."

${ }^{46}$ EIZIRIK, Nelson. 2011a, p 311.

${ }^{47}$ De acordo com o artigo 146 da Lei $n^{\circ}$ 6.404/76, "Poderão ser eleitas para membros dos órgãos de administração pessoas naturais, devendo os diretores ser residentes no País.”
} 
nada impede que o estatuto da companhia estabeleça, complementarmente, requisitos mínimos, de caráter geral, para a eleição dos Administradores ${ }^{48}$.

Conforme exposto anteriormente, os Administradores conduzem os negócios sociais e representam a companhia - dentro de suas respectivas esferas de competência - de maneira que, na qualidade de representantes, quando praticam atos jurídicos, manifestam a vontade da companhia e esta por eles se obriga ${ }^{49}$.

Por terem tais atribuições, o desempenho dos Administradores possui, na estrutura de uma companhia, suma responsabilidade e importância no sucesso ou no insucesso da empresa, tendo em vista que reunindo capitais de incontáveis origens, e número ilimitado de acionistas, a administração de uma companhia conta com dificuldades que não encontram solução em texto de lei nem em normas de caráter disciplinar, e sim, na atuação dos que a exercem ${ }^{50}$.

É importante que os Administradores tenham a liberdade necessária para atuarem nos seus respectivos papeis, nos quais se sintam à vontade para apresentar ideias e projetos para a companhia, obviamente que sempre em prol da melhor realização de seus negócios, e, ao mesmo tempo, devem ter o discernimento das consequências que lhes podem ser imputadas por seus atos.

Arnoldo Wald sintetiza esta ideia:

\begin{abstract}
"No plano societário, como no político, trata-se, atualmente, de conciliar o tecnicamente ideal, o politicamente possível e a otimização da rentabilidade, o que pressupõe um sistema de ampla liberdade, com a consequente responsabilidade, para os administradores, que deve recair tanto sobre os diretores quanto sobre os Conselhos que representam os acionistas (Conselho de Administração no Brasil, Conselho Diretor nos Estados Unidos)., ${ }^{\text {,1 }}$
\end{abstract}

\footnotetext{
${ }^{48}$ EIZIRIK, Nelson. 2011a., p 313.

${ }^{49}$ Ibid. p. 257.

${ }^{50}$ PEDREIRA, José Luiz Bulhões; FILHO, Alfredo Lamy, 2009a, p. 792.

${ }^{51}$ WALD, Arnoldo. Op. cit., p. 177.
} 
Devido à enorme responsabilidade dos Administradores para com o desempenho do objeto social da companhia - e dos seus resultados propriamente ditos - é de extrema importância que permeiem deveres e responsabilidades no âmbito de suas atuações.

José Xavier Carvalho de Mendonça, a seguir, sintetiza brilhantemente esta ideia:

\begin{abstract}
"É verdade cediça que dos administradores dependem a prosperidade e o êxito da sociedade. De um lado, os acionistas quase se não preocupam com a sociedade nem fiscalizam a ação dos administradores, enquanto percebem dividendos; do outro, os administradores, gerindo o alheio, nem sempre dedicam à sociedade a solicitude do sócio-gerente de responsabilidade ilimitada na sociedade, em nome coletivo. Na prática, fraquíssima é a influência das assembleias gerais sobre os administradores. Há, portanto, necessidade de leis completas que regulem a administração da sociedade, não podendo ser modificadas pelos estatutos no sentido de diminuírem-se atribuições e responsabilidades." ${ }^{52}$
\end{abstract}

Assim, diante de tamanha responsabilidade, a Lei $\mathrm{n}^{\circ}$ 6.404/76, estabelece deveres e responsabilidades com o fim de nortear a conduta dos Administradores no regime de suas funções.

\footnotetext{
${ }^{52}$ CARVALHO DE MENDONÇA, José Xavier. Op. cit., p. 39.
} 


\section{CAPÍTULO 2. DOS DEVERES DOS ADMINISTRADORES}

Na Seção IV do Capítulo XII da Lei nº 6.404/76, constituem-se os deveres e responsabilidades dos Administradores, os quais são temas de grande importância no regramento referente a uma companhia ${ }^{53}$.

O legislador estabeleceu um sistema descritivo no qual os deveres dos administradores são expostos nos artigos 153 a 157, seguidamente de suas responsabilidades no artigo $158^{54}$ e no artigo $159^{55}$ encerra-se a Seção tratando da ação de responsabilidade civil contra administrador por prejuízos causados ${ }^{56}$.

Os principais deveres elencados pela Lei $\mathrm{n}^{0} \quad 6.404 / 76$ aos Administradores são os deveres: (i) de diligência (artigo 15357); (ii) o de cumprimento das finalidades da sociedade (artigo $154^{58}$ ); (iii) o de lealdade

${ }^{53}$ CAMPOS, Luiz Antonio de Sampaio in FILHO, Alfredo Lamy; PEDREIRA, José Luiz Bulhões, 2009a, p. 1084.

${ }^{54}$ De acordo com o artigo 158 da Lei $\mathrm{n}^{\circ}$ 6.404/76, “O administrador não é pessoalmente responsável pelas obrigações que contrair em nome da sociedade e em virtude de ato regular de gestão; responde, porém, civilmente, pelos prejuízos que causar, quando proceder: I - dentro de suas atribuições ou poderes, com culpa ou dolo; II - com violação da lei ou do estatuto.”

${ }^{55}$ De acordo com o artigo 159 da Lei $\mathrm{n}^{\circ}$ 6.404/76, "Compete à companhia, mediante prévia deliberação da assembleia geral, a ação de responsabilidade civil contra o administrador, pelos prejuízos causados ao seu patrimônio.”

56 CAMPOS, Luiz Antonio de Sampaio in FILHO, Alfredo Lamy; PEDREIRA, José Luiz Bulhões, Op.cit. p. 1085.

${ }^{57}$ De acordo com o artigo 153 da Lei no 6.404/76, “O administrador da companhia deve empregar, no exercício de suas funções, o cuidado e diligência que todo homem ativo e probo costuma empregar na administração dos seus próprios negócios".

${ }^{58}$ De acordo com o artigo 154 da Lei ${ }^{\circ}$ 6.404/76, "O administrador deve exercer as atribuições que a lei e o estatuto lhe conferem para lograr os fins e no interesse da companhia, satisfeitas as exigências do bem público e da função social da empresa”. 
(artigo 155 59 ); o de evitar situações de conflitos de interesses (artigo 156 ${ }^{60}$ ); e o de informar (artigo $157^{61}$ ).

Observa-se na descrição dos deveres impostos aos Administradores que o legislador intencionalmente optou por mesclar princípios e comportamentos - ainda que de forma expositiva - em suas descrições como uma forma de preocupação em prover um guia seguro de orientação de atuação aos Administradores ${ }^{62}$, sobre o que devem ou não devem fazer, facilitando ainda a apuração de sua responsabilidade em hipótese de não observância $^{63}$.

Por ter adotado conceitos de formas gerais aos padrões de conduta dos Administradores, no que tange a seus comportamentos positivos e negativos, a Lei $n^{0}$ 6.404/76 conferiu ao intérprete e ao aplicador da lei uma determinada liberdade de interpretação que deve ser usada cautelosamente, como nos ensina o advogado Luiz Antonio de Sampaio Campos:

"Essa liberdade, típica das cláusulas gerais e dos conceitos jurídicos indeterminados, deve, porem, ser usada de forma inteligente e cuidadosa, a manter o sistema integro, para não desencorajar e afastar pessoas honestas e competentes dos cargos de administradores, e também de modo a não criar um sistema que as entorpeça a ação com uma burocracia prejudicial à vida da companhia, afastando-as do risco inerente ao negocio". ${ }^{64}$

\footnotetext{
${ }^{59}$ De acordo com o artigo 155 da Lei $n^{\circ}$ 6.404/76, “O administrador deve servir com lealdade à companhia e manter reserva sobre os seus negócios, sendo-lhe vedado: I - usar, em benefício próprio ou de outrem, com ou sem prejuízo para a companhia, as oportunidades comerciais de que tenha conhecimento em razão do exercício de seu cargo; II - omitir-se no exercício ou proteção de direitos da companhia ou, visando à obtenção de vantagens, para si ou para outrem, deixar de aproveitar oportunidades de negócio de interesse da companhia; III - adquirir, para revender com lucro, bem ou direito que sabe necessário à companhia, ou que esta tencione adquirir."

${ }^{60}$ De acordo com artigo 156 da Lei $n^{\circ}$ 6.404/76, "É vedado ao administrador intervir em qualquer operação social em que tiver interesse conflitante com o da companhia, bem como na deliberação que a respeito tomarem os demais administradores, cumprindo-lhe cientificá-los do seu impedimento e fazer consignar, em ata de reunião do conselho de administração ou da diretoria, a natureza e extensão do seu interesse".

${ }^{61}$ De acordo com o artigo 157 da Lei $n^{\circ}$ 6.404/76, "O administrador de companhia aberta deve declarar, ao firmar o termo de posse, o número de ações, bônus de subscrição, opções de compra de ações e debêntures conversíveis em ações, de emissão da companhia e de sociedades controladas ou do mesmo grupo, de que seja titular".

${ }_{62}$ CAMPOS, Luiz Antonio de Sampaio in FILHO, Alfredo Lamy; PEDREIRA, José Luiz Bulhões, 2009a, p. 1085.

${ }^{63}$ QUATTRINI, Larissa Teixeira. Os Deveres dos Administradores de Sociedades Anônimas Abertas: Estudo de Casos. São Paulo: Saraiva, 2014. P. 23.

${ }_{64}$ CAMPOS, Luiz Antonio de Sampaio in FILHO, Alfredo Lamy; PEDREIRA, José Luiz Bulhões, Op.cit., p. 1087.
} 
O grande objetivo da Lei ao incluir esta Seção foi o de impedir que os Administradores colocassem seus interesses pessoais à frente dos interesses da companhia e de seus acionistas como um todo, ou ainda que fossem negligentes no desempenho de suas funções como membros dos Órgãos de Administração ${ }^{65}$.

Vale ressaltar que, na hipótese de aplicação dos dispositivos da Lei $n^{\circ}$ 6.404/76 com relação aos deveres e responsabilidades dos Administradores, devem ser observadas as funções desempenhadas pelos respectivos membros dos Órgãos de Administração - conselheiros e diretores - para que não gere nenhum equívoco, conforme expõe Luiz Antonio de Sampaio Campos, em seu voto como Diretor da Comissão de Valores Mobiliários - CVM, a seguir:

“(...) é de capital importância que os dispositivos referentes a deveres e responsabilidades dos administradores não sejam aplicados mecanicamente, sem prévia interpretação, à luz das estruturas, modalidades e atividades dos órgãos da administração e, mais ainda, do mundo real, para se evitar os excessos utópicos, de que falava a exposição de motivos da anteprojeto da Lei 6.404/76. É fundamental que, no momento de se aplicar estes dispositivos, se mergulhe, profundamente, nas estruturas destes órgãos sociais, conselho de administração e diretoria, e suas respectivas formas de atuar, sem se ignorar as suas especificidades, desde o modo de atuação, notadamente quanto à forma de deliberação."66

Além destes, há outros deveres que se encontram dispersos na Lei, como, por exemplo, os de convocar a assembleia geral ordinária (artigo $123^{67}$ ); divulgar e deixar à disposição dos acionistas até um mês antes da assembleia geral ordinária, os documentos da administração (artigo $133^{68}$ );

65 CAMPOS, Luiz Antonio de Sampaio in FILHO, Alfredo Lamy; PEDREIRA, José Luiz Bulhões, 2009a, p. 1090.

${ }^{66}$ CVM, Inquérito Administrativo CVM no TA-RJ 2002/1173, Diretor Luiz Antonio de Sampaio Campos, Rio de Janeiro, 2 de outubro de 2003.

${ }^{67}$ De acordo com o artigo 123 da Lei n ${ }^{\circ}$ 6.404/76, "Compete ao conselho de administração, se houver, ou aos diretores, observado o disposto no estatuto, convocar a assembléia-geral.”

68 De acordo com o artigo 133 da Lei $n^{\circ}$ 6.404/76, "Os administradores devem comunicar, até 1 (um) mês antes da data marcada para a realização da assembleia geral ordinária, por anúncios publicados na forma prevista no artigo 124, que se acham à disposição dos acionistas: I - o relatório da administração sobre os negócios sociais e os principais fatos administrativos do exercício findo; II - a cópia das demonstrações financeiras; III - o parecer dos auditores 
estar presente pelo menos um dos Administradores à assembleia geral ordinária (artigo 134 e parágrafos ${ }^{69}$ ); providenciar as demonstrações financeiras (artigo $176^{70}$ ); zelar para que as operações entre sociedades coligadas, controladoras ou controladas observem condições estritamente comutativas (artigo $245^{71}$ ); quando for administrador de sociedade filiada, observar a orientação e as instruções expedidas pelos administradores do grupo (artigo $273^{72}$ ) e zelar para que não ocorram prejuízos decorrentes de atos estranhos à convenção instituidora de agrupamento (artigo 276, $\left.\S 3^{0^{73}}\right)^{74}$

independentes, se houver; IV - o parecer do conselho fiscal, inclusive votos dissidentes, se houver; e V - demais documentos pertinentes a assuntos incluídos na ordem do dia.

${ }^{69}$ De acordo com o artigo134, caput, e $\S \S 1^{\circ}$ a $6^{\circ}$, "Art. 134. Instalada a assembleia geral, proceder-se-á, se requerida por qualquer acionista, à leitura dos documentos referidos no artigo 133 e do parecer do conselho fiscal, se houver, os quais serão submetidos pela mesa à discussão e votação. § $1^{\circ}$ Os administradores da companhia, ou ao menos um deles, e o auditor independente, se houver, deverão estar presentes à assembleia para atender a pedidos de esclarecimentos de acionistas, mas os administradores não poderão votar, como acionistas ou procuradores, os documentos referidos neste artigo. ; $\S 2^{\circ}$ Se a assembleia tiver necessidade de outros esclarecimentos, poderá adiar a deliberação e ordenar diligências; também será adiada a deliberação, salvo dispensa dos acionistas presentes, na hipótese de não comparecimento de administrador, membro do conselho fiscal ou auditor independente. ; § $3^{\circ} \mathrm{A}$ aprovação, sem reserva, das demonstrações financeiras e das contas, exonera de responsabilidade os administradores e fiscais, salvo erro, dolo, fraude ou simulação (artigo 286). ; § $4^{\circ}$ Se a assembleia aprovar as demonstrações financeiras com modificação no montante do lucro do exercício ou no valor das obrigações da companhia, os administradores promoverão, dentro de 30 (trinta) dias, a republicação das demonstrações, com as retificações deliberadas pela assembleia; se a destinação dos lucros proposta pelos órgãos de administração não lograr aprovação (artigo 176, § $3^{\circ}$ ), as modificações introduzidas constarão da ata da assembleia.; $\S 5^{\circ} \mathrm{A}$ ata da assembleia geral ordinária será arquivada no registro do comércio e publicada.; § $6^{\circ}$ As disposições do $\S 1^{\circ}$, segunda parte, não se aplicam quando, nas sociedades fechadas, os diretores forem os únicos acionistas.

${ }^{70}$ De acordo com o artigo 176 da Lei n ${ }^{\circ} 6.404 / 76$, “Ao fim de cada exercício social, a diretoria fará elaborar, com base na escrituração mercantil da companhia, as seguintes demonstrações financeiras, que deverão exprimir com clareza a situação do patrimônio da companhia e as mutações ocorridas no exercício: I - balanço patrimonial; II - demonstração dos lucros ou prejuízos acumulados; III - demonstração do resultado do exercício; IV - demonstração dos fluxos de caixa; e V - se companhia aberta, demonstração do valor adicionado.”

${ }^{71}$ De acordo com o artigo 245 da Lei no $6.404 / 76$, “Os administradores não podem, em prejuízo da companhia, favorecer sociedade coligada, controladora ou controlada, cumprindo-lhes zelar para que as operações entre as sociedades, se houver, observem condições estritamente comutativas, ou com pagamento compensatório adequado; e respondem perante a companhia pelas perdas e danos resultantes de atos praticados com infração ao disposto neste artigo.”

${ }_{72}$ De acordo com o artigo 273 da Lei $\mathrm{n}^{\circ}$ 6.404/76, "Os administradores do grupo e os investidos em cargos de mais de uma sociedade poderão ter a sua remuneração rateada entre as diversas sociedades, e a gratificação dos administradores, se houver, poderá ser fixada, dentro dos limites do $\S 1^{\circ}$ do artigo 152 com base nos resultados apurados nas demonstrações financeiras consolidadas do grupo."

${ }^{73}$ De acordo com o $\$ 3^{\circ}$ do artigo 276, “Os sócios minoritários da filiada terão ação contra os seus administradores e contra a sociedade de comando do grupo para haver reparação de prejuízos resultantes de atos praticados com infração das normas deste artigo, observado o disposto nos parágrafos do artigo 246.”

${ }^{74}$ PARENTE, Flávia. Op. cit., p. 33. 
Fábio Ulhoa Coelho sustenta que existem ainda deveres implícitos aos Administradores, os quais se percebem por normas gerais, ou mesmo a partir de princípios que regem o direito societário brasileiro. Em suas palavras:

"São dessa categoria os deveres de observar os estatutos, cumprir as deliberações dos órgãos societários hierarquicamente superiores, controlar a atuação dos demais administradores, não competir com a sociedade etc.,"75

Fora a finalidade de proteger a própria companhia, e a observância de que seus negócios estão sendo conduzidos de maneira diligente, estes deveres dos Administradores buscam a proteção dos acionistas no intuito de que não tenham seus direitos frustrados por razões que fogem à condução propriamente dita da gestão de uma companhia.

\subsection{Dever de Diligência}

O artigo 153 da Lei $n^{\circ}$ 6.404/76 dispõe que "o administrador da companhia deve empregar, no exercício de suas funções, o cuidado e diligência que todo homem ativo e probo costuma empregar na administração dos seus próprios negócios”.

Tal dispositivo figura-se como o primeiro dever na Seção de Deveres e Responsabilidades dos Administradores e, como se refere o advogado Luiz Antonio de Sampaio Campos, "é a pedra de toque da atuação dos Administradores”76. Isto porque é a regra suprema do norte de atuação dos Administradores, pela qual se estabelece um comportamento, um padrão geral de conduta, uma orientação flexível, cuja aplicabilidade deve ser verificada caso a caso, e que se desdobram os demais deveres ${ }^{77}$.

\footnotetext{
${ }^{75}$ COELHO, Fábio Ulhoa. Curso de Direito Comercial, volume 2: Direito de Empresa. São Paulo: Saraiva, 2010, p. 253.

76 CAMPOS, Luiz Antonio de Sampaio in FILHO, Alfredo Lamy; PEDREIRA, José Luiz Bulhões, 2009a, p. 1.097.

${ }^{77}$ EIZIRIK, Nelson. 2011a, p 349.
} 
A importância do dever de diligência reside ainda no fato de se constituir não só um dever, e sim, um princípio geral $^{78}$ de direito que sempre acompanha a execução ou o cumprimento de qualquer obrigação, e a sua transposição ao âmbito da gestão das companhias ${ }^{79}$.

O dever de diligência dos Administradores distingue-se deste dever quanto aos demais devedores de obrigações em geral. Enquanto que para estes corresponde ao grau de esforço exigível de alguém para que cumpra determinada obrigação, dos Administradores exige mais do que o mero cumprimento do dever de desempenhar suas funções em seus respectivos cargos, demanda dos Administradores dedicação, atenção, zelo e cuidado, ou seja, uma atuação competente e profissional ${ }^{80}$.

A origem do dever de diligência vem do princípio do bonus pater familias, do direito romano ${ }^{81}$, que designava a pessoa que administrava seus interesses com cuidado, zelo e prudência. Ainda, segundo o jurista Modesto Carvalhosa $^{82}$, a presença do vernáculo “cuidado” do artigo 153 indica claramente uma nítida influência do standard of care do direito norteamericano, um padrão de conduta, contatando-se que o legislador teve, portanto, o objetivo de combinar tais cuidados, zelo e prudência do bom pai de família com a aptidão para a realização de negócios do businessman do direito anglo-saxão ${ }^{83}$.

Esta combinação faz total sentido, uma vez que o modelo do teórico bom pai de família ${ }^{84}$ nos remete a uma pessoa conservadora e avessa a riscos, que estaria mais preocupada em preservar o patrimônio do que aumentá-lo, sendo que o objeto de uma companhia, no sentido da busca

\footnotetext{
${ }^{78}$ PARENTE, Flávia. Op. cit., p. 41.

${ }^{79}$ EIZIRIK, Nelson. 2011a, p 349.

${ }^{80}$ PARENTE, Flávia. Op. cit., p. 42.

${ }^{81}$ CARVALHOSA, Modesto. Op. cit., p 274.

${ }^{82}$ Ibid. p. 271.

83 CAMPOS, Luiz Antonio de Sampaio in FILHO, Alfredo Lamy; PEDREIRA, José Luiz Bulhões, 2009a, p. 1.100.

${ }^{84}$ PARENTE, Flávia. Op. cit., p. 43.
} 
pela maximização dos lucros, pressupõe a propensão ao risco empresarial ${ }^{85}$, já o businessman nos remete a alguém com experiência no mundo empresarial.

O dever de diligência dos Administradores, por se tratar de uma orientação flexível $^{86}$, deve ser aplicado com prudência e moldado caso a caso, de acordo com o modelo de conduta média dos Administradores - que se verifica por meio da experiência comum - e levando em consideração ainda a natureza distinta dos poderes e competências conferidos pela Lei ${ }^{\circ}$ 6.404/76 aos respectivos Administradores - diretores e conselheiros - da companhia $^{87}$.

A Lei $n^{0}$ 6.404/76 não exige habilitações técnicas e profissionais específicas para o cargo de administrador, a experiência comum evidencia que uma excelente formação não traz necessariamente o sucesso empresarial. A Lei pretendeu estabelecer que o administrador ao ser indicado para o exercício do cargo avalie se obtém as condições necessárias para o desempenho da função e, caso não as obtenha, assumirá o rico de ser responsabilizado posteriormente por descumprimento do dever de diligência. Isto não significa que o administrador deve ser submetido a uma perícia específica para o cargo, mas que o administrador diligente não irá aventurar-se em assuntos nos quais lhe falta a devida perícia ${ }^{88}$.

O dever de diligência não requer a obtenção de um determinado resultado, mas sim que sejam empregados os seus melhores esforços para alcançá-lo ${ }^{89}$. Trata-se, portando, de uma obrigação de meio, e não de resultado, pela qual não infringe o dever de diligência o administrador que observou os comportamentos obrigatórios com a diligência devida, mas que

${ }^{85}$ CAMPOS, Luiz Antonio de Sampaio in FILHO, Alfredo Lamy; PEDREIRA, José Luiz Bulhões, Op. cit., p. 1.101.

${ }^{86}$ EIZIRIK, Nelson. 2011a, p 349.

${ }^{87}$ PARENTE, Flávia. Op. cit., p. 45.

${ }^{88}$ CAMPOS, Luiz Antonio de Sampaio in FILHO, Alfredo Lamy; PEDREIRA, José Luiz Bulhões,.Op.cit., p. 1.102.

${ }^{89}$ EIZIRIK, Nelson. 2011a, p 349. 
não alcançou os objetivos da companhia, ou que ainda tenham sido alcançados de maneira parcial $^{90}$.

Flavia Parente leciona a respeito:

“Tendo o administrador uma obrigação de meio e não de resultado, deduz-se que dele é exigível apenas a condução, de maneira diligente, dos negócios sociais de acordo com o interesse social, tendo em vista os postulados da administração de empresas. ${ }^{91,}$

O jurista José Alexandre Tavares Guerreiro sintetiza a respeito do dever de diligência:

"Parte a lei, no art. 153, do estabelecimento de um modelo de comportamento, isto é, de um padrão destinado a servir de medida ou elemento de comparação para juízo de casos concretos. O administrador da companhia deve empregar, no exercício de suas funções, o cuidado e diligência que todo homem ativo e probo costuma empregar na administração dos seus próprios negócios. Assim se descreve o dever básico do administrador, a que a lei chamou de dever de diligência, do qual, a bem dizer, os demais deveres são desdobramentos. ${ }^{92}$,

O dever de diligência se decompõe em cinco outros deveres, cujo exame é essencial para aferição ${ }^{93}$ do comportamento diligente de um administrador, são eles os deveres de: (i) se qualificar para o cargo; (ii) bem administrar; (iii) se informar; (iv) investigar; e (v) vigiar ${ }^{94}$.

\footnotetext{
${ }^{90}$ PARENTE, Flávia. Op. cit., p. 50.

${ }^{91}$ PARENTE, Flávia. Op. cit., p. 50.

92 TEIXEIRA, Egberto Lacerda; GUERREIRO, José Alexandre Tavares. Das Sociedades Anônimas no Direito Brasileiro, Volume 2. São Paulo: Bushatsky, 1979. P. 471.

${ }^{93}$ EIZIRIK, Nelson. 2011a, p 353.

${ }^{94}$ PARENTE, Flávia. Op. cit., p. 101.
} 


\subsection{Dos Deveres Abarcados no Dever de Diligência e da Business Judgment Rule}

\subsubsection{Dever de se Qualificar para o Cargo}

O administrador deve ter ou adquirir os conhecimentos técnicos mínimos sobre as atividades da companhia e a competência necessária ao desempenho de suas funções, para que tenha a capacidade técnica para tomar decisões de maneira refletida e responsável ${ }^{95}$. Isto é, não se exige que o administrador seja um técnico altamente especializado em todas as matérias que possam estar no âmbito de sua apreciação, mas sim, o mínimo de profissionalidade e perícia para o exercício da função, e caso não as tenha, deve o administrador, em nome do dever de diligência, não aceitar o cargo $^{96}$.

\subsubsection{Dever de Bem Administrar}

Este dever consiste na atuação do administrador visando à consecução do interesse social $^{97}$, ou seja, administrar uma companhia significa praticar todos os atos necessários à plena execução da vontade social, a fim de realizar o seu objeto social ${ }^{98}$.

Os Administradores têm, portanto, o dever de praticar os atos de gestão e de representação para os quais, conselheiros e diretores, foram respectivamente designados, devendo de fato exercer estes poderes ${ }^{99}$.

Dessa forma, os Administradores têm o dever de desempenhar o cargo de maneira diligente, isto é, o dever de desempenhar o cargo pressupõe o dever de administrar e o dever de atuar com diligência ${ }^{100}$.

\footnotetext{
${ }^{95}$ EIZIRIK, Nelson. 2011a, p 353.

${ }^{96}$ RIBEIRO, Renato Ventura. Dever de Diligência dos Administradores de Sociedades. São Paulo: Quarter Latin, 2006, p. 222.

${ }^{97}$ EIZIRIK, Nelson. Op.cit. p 353.

${ }^{98}$ PARENTE, Flávia. Op. cit., p. 108.

${ }^{99}$ Ibid., p. 110.
} 


\subsubsection{Dever de se Informar}

O administrador tem a obrigação de obter as informações necessárias sobre o desenvolvimento dos negócios da companhia de uma maneira geral, e obter os dados necessários para uma diligente tomada de decisão ${ }^{101}$.

A atuação de um administrador diligente pressupõe a obtenção das informações necessárias para se avaliar os riscos de um negócio, as vantagens e desvantagens que a sua tomada decisão envolverá ${ }^{102}$.

\subsubsection{Dever de Investigar}

Este dever se trata de uma decorrência do dever de se informar, o administrador deve manter uma postura ativa, devendo investigar o desenvolvimento das atividades da companhia ${ }^{103}$, o que lhe impõe a obrigação de analisar criticamente as informações que recebe, no intuito de detectar potenciais problemas que possam vir a surgir em decorrência do desenvolvimento de tais atividades ${ }^{104}$.

\subsubsection{Dever de Vigiar}

Este dever está vinculado ao dever de investigar, consistindo na obrigação dos Administradores de vigiarem, ou monitorarem, o desenvolvimento das atividades da companhia ${ }^{105}$.

\footnotetext{
${ }^{100}$ PARENTE, Flávia. Op. cit., p. 110.

101 CAMPOS, Luiz Antonio de Sampaio in FILHO, Alfredo Lamy; PEDREIRA, José Luiz Bulhões, 2009a, p. 1.106.

102 Ibid. p. 1.102.

${ }^{103}$ EIZIRIK, Nelson. 2011a, p 355.

${ }^{104}$ PARENTE, Flávia. Op. cit., p. 119.

${ }^{105}$ Ibid.
} 
Exige-se dos Administradores por este dever, não a obrigação de examinar detalhadamente todas as operações da companhia, mas sim uma vigilância geral, no sentido de fiscalizar o andamento dos seus negócios e a execução das deliberações e decisões tomadas ${ }^{106}$.

\subsubsection{Business Judgment Rule}

A Business Judgment Rule é uma construção jurisprudencial do Direito norte-americano, que visa dar liberdade aos Administradores para decidirem sobre a oportunidade e conveniência dos seus atos, e lhes oferecer uma proteção acerca das decisões tomadas, de boa-fé, no interesse da sociedade e com base em informações razoáveis e em respeito ao dever de diligência, sem que estas sejam revistas pelos tribunais e, além disso, sem que sejam sujeitos à responsabilização na hipótese de tais decisões se revelarem inadequadas ou mal sucedidas ${ }^{107}$.

No Direito Societário brasileiro a business judgment rule é comumente referida como a "regra do julgamento do negócio",108, encontrando previsão legal no artigo 159 , $\S 6^{\circ}$, da Lei $n^{\circ} 6.404 / 76^{109}$, e tem como seu principal campo de aplicação os Processos Administrativos Sancionadores da Comissão de Valores Mobiliários - CVM.

Luiz Antonio de Sampaio Campos sintetizou a ideia do business judgment rule em um de seus votos enquanto Diretor da Comissão de Valores Mobiliários:

“(...) a Lei ${ }^{0}$ 6.404/76, que numa "tropicalização” da business judgment rule permite inclusive que se exclua a responsabilidade dos administradores, quando

\footnotetext{
106 CAMPOS, Luiz Antonio de Sampaio in FILHO, Alfredo Lamy; PEDREIRA, José Luiz Bulhões, 2009a, p. 1.107.

${ }^{107}$ PARENTE, Flávia. Op. cit., p. 71.

108 NASCIMENTO, João Pedro Barroso do in SILVA, Alexandre Couto. Direito Societário: Estudos sobre a Lei de Sociedade por Ações. São Paulo: Saraiva, 2013. P.172.

${ }^{109}$ De acordo com o $\S 6^{\circ}$ do art. 159 da Lei $n^{\circ}$ 6.404/76, “O juiz poderá reconhecer a exclusão da responsabilidade do administrador, se convencido de que este agiu de boa-fé e visando ao interesse da companhia.”
} 
se verificar que estes mesmo violando a lei agiram de boa-fé e no interesse da companhia, conforme expressamente o parágrafo $6^{\circ}$ do art. 159. Assim, segundo penso, os administradores e os acionistas têm discricionariedade para gerir o caixa da companhia e tomar as decisões que entenderem mais apropriadas ao interesse da companhia."110

A lógica desta regra consiste em reconhecer que a autoridade jurisdicional não deve rever o mérito das decisões negociais tomadas pela administração, para que desta forma possa encorajar os Administradores a servirem à companhia, de forma equilibrada e alinhada com os deveres que lhes são impostos, porém, assumindo os riscos inerentes à atividade empresarial e que podem vir a ser benéficos para a companhia ${ }^{111}$.

Flávia Parente ensina o objetivo desta regra:

\begin{abstract}
“A business judgment rule tem por finalidade oferecer ampla proteção às decisões de negócios bem informadas, constituindo uma espécie de "porto seguro" para os administradores, que devem ser encorajados não apenas a assumir cargos de administração, como também a correr determinados riscos que são inerentes à gestão empresarial. Com efeito, as pessoas competentes devem ser estimuladas a aceitar a função de administradores, sendo conveniente que disponham de amplos poderes para conduzir os negócios sociais.”
\end{abstract}

É importante ressaltar que a business judgment rule não visa proteger toda e qualquer decisão de gestão tomada pelo administrador, de forma que esta regra não pode ser entendida como uma excludente definitiva do controle jurisdicional no âmbito das decisões tomadas pela administração da companhia, mas sim uma regra que tem como objetivo trazer um equilíbrio para evitar excessos no controle jurisdicional em relação a atos de gestão e decisões negociais ${ }^{112}$.

\footnotetext{
${ }^{110}$ CVM, Processo Administrativo Sancionador CVM no 03/02, Diretor Luiz Antonio de Sampaio Campos, Rio de Janeiro, 12 de fevereiro de 2004.

${ }^{111}$ NASCIMENTO, João Pedro Barroso do in SILVA, Alexandre Couto, op. cit. P. 173.

${ }^{112}$ NASCIMENTO, João Pedro Barroso do in SILVA, Alexandre Couto, op. cit. P. 175.
} 


\section{Capítulo 3. DAS SOCIEDADES DE ECONOMIA MISTA}

\subsection{Regime Jurídico}

A sociedade de economia mista - junto com a empresa pública constitui um dos principais instrumentos utilizados pelo Estado para intervir como empresário no domínio econômico ${ }^{113}$, sendo ambas integrantes da Administração Indireta do Estado ${ }^{114}$, conforme disposto no artigo 4º II, "b" e "c" do Decreto-Lei no 200, de 25 de fevereiro de $1967^{115}$.

$\mathrm{O}$ acionista controlador da sociedade de economia mista, direta ou indiretamente, é sempre o Estado, seja na esfera municipal, estadual ou federal. Sendo este controle sempre majoritário, uma vez que o Estado deve ser titular da maioria das ações com direito a voto ${ }^{116}$.

Em nosso sistema jurídico as sociedades de economia mista são disciplinadas por meio de normas de diferentes origens e hierarquias, sendo elas: (i) constitucionais; (ii) administrativas; (iii) de direito privado (a Lei $\mathrm{n}^{\circ}$ 6.404/76); e (iv) especiais, as quais regulam a constituição de tais sociedades ${ }^{117}$.

As sociedades de economia mista encontram base legal no artigo 173 da Constituição da República Federativa do Brasil de $1988^{118}$, estão sujeitas ao regime das sociedades por ações, conforme disposto no artigo 235 da Lei

\footnotetext{
${ }^{113}$ EIZIRIK, Nelson. A Lei das S/A Comentada. Volume III - Arts. 189 a 300. São Paulo: Editora Quartier Latin, 2011b, p. 284.

${ }^{114}$ EIZIRIK, Nelson,2011b, p. 292.

${ }^{115}$ De acordo com artigo 4을 inciso II, alíneas "b" e "c" do Decreto-Lei no 200, de 25 de fevereiro de 1967, “A Administração Federal compreende: II - A Administração Indireta, que compreende as seguintes categorias de entidades, dotadas de personalidade jurídica própria: b) Emprêsas Públicas; c) Sociedades de Economia Mista.”

${ }^{116}$ EIZIRIK, Nelson, Op.cit, p. 312.

${ }^{117}$ Ibid. p. 293.

${ }^{118}$ De acordo com o artigo 173 da Constituição Federal da República de 1988, "Ressalvados os casos previstos nesta Constituição, a exploração direta de atividade econômica pelo Estado só será permitida quando necessária aos imperativos da segurança nacional ou a relevante interesse coletivo, conforme definidos em lei.”
} 
$\mathrm{n}^{\mathrm{o}} 6.404 / 76^{119}$, e são reguladas ainda pelo Decreto-Lei $\mathrm{n}^{\mathrm{o}} 200$, de 25 de fevereiro de $1967^{120}$, e pelo Decreto $n^{\circ} 1.091$, de 21 de março de $1994^{121}$.

O Decreto-Lei n 200/1967, em seu artigo 5º, III, com a redação dada pelo Decreto-Lei $n^{\circ}$ 900/1969, instituiu a seguinte definição para as sociedades de economia mista:

"Sociedade de Economia Mista - a entidade dotada de personalidade jurídica de direito privado, criada por lei para a exploração de atividade econômica, sob a forma de sociedade anônima, cujas ações com direito a voto pertençam em sua maioria à União ou a entidade da Administração Indireta.”

Partindo deste conceito, temos 3 (três) elementos caracterizadores de uma sociedade de economia mista: (i) a sua constituição mediante lei específica; (ii) a adoção da personalidade jurídica de direito privado; e (iii) a titularidade da maioria do capital votante por parte do Estado, direta ou indiretamente $\mathrm{e}^{122}$.

O funcionamento do Conselho Fiscal das sociedades de economia mista será permanente, sendo que um dos seus membros, e respectivo suplente, será eleito pelas ações ordinárias minoritárias, e outro pelas ações preferenciais, se houver, conforme artigo $240^{123}$ da Lei ${ }^{\circ} 6.404 / 76$.

No artigo 37, XIX, da Constituição da República Federativa do Brasil de $1988^{124}$ e, também, no artigo 236 da Lei no $6.404 / 76^{125}$, temos a

\footnotetext{
${ }^{119}$ De acordo com o artigo 235 da Lei no 6.404/76, "As sociedades anônimas de economia mista estão sujeitas a esta Lei, sem prejuízo das disposições especiais de lei federal.”

${ }^{120}$ O Decreto-Lei n⿳亠丷厂 200, de 25 de fevereiro de 1967 dispõe sobre a organização da Administração Federal, estabelece diretrizes para a Reforma Administrativa e dá outras providências.

${ }^{121}$ O Decreto ${ }^{\circ}$ 1.091, de 21 de março de 1994 dispõe sobre procedimentos a serem observados por empresas controladas direta ou indiretamente pela União.

${ }^{122}$ EIZIRIK, Nelson,2011b, p. 293.

${ }^{123}$ De acordo com o artigo 240 da Lei $n^{\circ}$ 6.404/76, "O funcionamento do conselho fiscal será permanente nas companhias de economia mista; um dos seus membros, e respectivo suplente, será eleito pelas ações ordinárias minoritárias e outro pelas ações preferenciais, se houver.”

${ }^{124}$ De acordo com o artigo 37, inciso XIX, da Constituição da República Federativa do Brasil de 1988, "A administração pública direta e indireta de qualquer dos Poderes da União, dos Estados, do Distrito Federal e dos Municípios obedecerá aos princípios de legalidade, impessoalidade, moralidade, publicidade e eficiência e, também, ao seguinte: XIX - somente por lei específica poderá ser criada autarquia e autorizada a instituição de empresa pública, de sociedade de economia mista e de fundação, cabendo à lei complementar, neste último caso, definir as áreas de sua atuação;”.

${ }^{125}$ De acordo com o artigo 236 da Lei no 6.404/76, “A constituição de companhia de economia mista depende de prévia autorização legislativa”.
} 
exigência de que a sociedade de economia mista seja criada por meio de lei específica.

Eros Grau diz que “o elemento primordial a caracterizá-la como uma sociedade de economia mista é a sua criação por lei”" ${ }^{126}$.

A Constituição da República Federativa do Brasil de 1988, em seu artigo 173 , $\S 1^{\circ}$, $\mathrm{II}^{127}$, determina que a sociedade de economia mista e suas subsidiárias que exploram atividade econômica de produção ou comercialização de bens ou prestação de serviços, estão submetidas ao regime próprio das empresas privadas, inclusive quanto aos direitos e obrigações civis, comerciais, trabalhistas e fiscais. $\mathrm{O}$ intuito de submeter a sociedade de economia mista exploradora de atividade econômica ao regime de direito privado visa a conferir-lhe a necessária flexibilidade para que possa competir adequadamente com seus concorrentes nos mercados nacional e internacional ${ }^{128}$.

O artigo 235, § $1^{\circ}$ da Lei ${ }^{\circ}$ 6.404/76 estabelece que as companhias abertas de economia mista estão sujeitas às normas expedidas pela Comissão de Valores Mobiliários - CVM. O artigo 236 dispõe ainda que a constituição de companhia de economia mista depende de prévia autorização legislativa. Isto foi estabelecido com o propósito de evitar a criação indiscriminada dessas empresas, considerando que sua criação é submetida à avaliação do Poder Legislativo, serão levados em consideração os aspectos de conveniência e necessidade.

O artigo 173 da Constituição da República Federativa do Brasil de 1988 dispõe que, ressalvados os casos nela previstos, a exploração direta de atividades econômicas pelo Estado só será permitida quando necessária aos

\footnotetext{
${ }^{126}$ GRAU, Eros Roberto. Lucratividade e Função Social nas Empresas sob Controle do Estado. Revista de Direito Mercantil. vol 55. São Paulo: Malheiros, p. 58.

${ }^{127}$ De acordo com o artigo 173, §1 ${ }^{\circ}$, inciso II da Constituição da República Federativa do Brasil de 1988, "Ressalvados os casos previstos nesta Constituição, a exploração direta de atividade econômica pelo Estado só será permitida quando necessária aos imperativos da segurança nacional ou a relevante interesse coletivo, conforme definidos em lei. $\S 1^{\circ} \mathrm{A}$ lei estabelecerá o estatuto jurídico da empresa pública, da sociedade de economia mista e de suas subsidiárias que explorem atividade econômica de produção ou comercialização de bens ou de prestação de serviços, dispondo sobre: II - a sujeição ao regime jurídico próprio das empresas privadas, inclusive quanto aos direitos e obrigações civis, comerciais, trabalhistas e tributários;”.

${ }^{128}$ EIZIRIK, Nelson,2011b, p. 294.
} 
imperativos da segurança nacional ou a relevante interesse coletivo. $\mathrm{O}$ artigo 237, §§ $1^{\circ}$ e $2^{\circ}$, da Lei $n^{\circ} 6.404 / 76$, também têm o propósito de restringir a expansão do setor público, podendo a sociedade de economia mista somente explorar empreendimentos e exercer atividades previstas na lei que autorizou a sua constituição.

O artigo 238 da Lei $n^{\circ}$ 6.404/76 determina que a pessoa jurídica que controla a companhia de economia mista tem os deveres e responsabilidades do acionista controlador (artigos 116 e 117 da Lei ${ }^{\circ}$ 6.404/76), mas poderá orientar as atividades da companhia de modo a atender ao interesse público que justificou a sua criação. Temos assim que, o controlador da sociedade de economia mista está equiparado ao acionista controlador da sociedade por ações, de forma que devem ser observados os requisitos do artigo 116 da Lei $\mathrm{n}^{\circ}$ 6.404/76. O referido artigo disciplina que o acionista controlador deve usar o seu poder de controle, a fim de fazer a companhia realizar seu objeto e cumprir sua função social, tendo ao mesmo tempo os deveres e responsabilidades para com os que trabalham na companhia, para a comunidade em que atua, e para com os demais acionistas da empresa, cujos direitos e interesses devem lealmente respeitar e atender, respondendo na hipótese de ocorrência de abuso de poder o acionista controlador pelos danos causados (artigo 117).

Por fazer parte da Administração Indireta do Estado, impõe-se às sociedades de economia mista o controle do Tribunal de Contas da União, conforme disposto no artigo 71, II da Constituição da República Federativa do Brasil de $1988^{129}$.

Dessa forma, percebemos que as normas de direito público aplicáveis à sociedade de economia mista concentram-se em 2 (duas) áreas: (i) nas suas relações com a pessoa jurídica que a instituiu; e (ii) nos seus

\footnotetext{
${ }^{129}$ De acordo com o artigo 71, inciso II da Constituição da República Federativa do Brasil de 1988, "O controle externo, a cargo do Congresso Nacional, será exercido com o auxílio do Tribunal de Contas da União, ao qual compete: II - julgar as contas dos administradores e demais responsáveis por dinheiros, bens e valores públicos da administração direta e indireta, incluídas as fundações e sociedades instituídas e mantidas pelo Poder Público federal, e as contas daqueles que derem causa a perda, extravio ou outra irregularidade de que resulte prejuízo ao erário público;”.
} 
mecanismos de controle, mediante procedimentos como a supervisão ministerial e a fiscalização do emprego de recursos públicos por parte do Tribunal de Contas ${ }^{130}$.

Com relação à administração das sociedades de economia mista, o artigo 239 da Lei $n^{\circ}$ 6.404/76 regulou a obrigatoriedade da existência do Conselho de Administração, seja ela companhia aberta ou fechada, sendo assegurado aos acionistas minoritários o direito de eleger um dos conselheiros, se maior número não lhes couber pelo processo de voto múltiplo. Ainda, a lei de criação da sociedade de economia mista poderá estabelecer que cargos das administração sejam providos por pessoas indicadas ou nomeadas por autoridades públicas ${ }^{131}$.

Aos Administradores de sociedades de economia mista aplicam-se os mesmos deveres e responsabilidades dos administradores das companhias abertas, conforme disposto no artigo 238 da Lei n ${ }^{\circ}$ 6.404/76, devendo cumprir os deveres que constam nos artigos 153 a 158 da Lei ${ }^{0}$ 6.404/76, e estando sujeitos à ação de responsabilidade civil de que trata o artigo 159, além das normas das companhias abertas editadas pela Comissão de Valores Mobiliários - CVM.

A responsabilidade dos administradores do ponto de vista da legislação societária é a mesma, sejam eles indicados por acionistas minoritários (ou privados, no caso de sociedade de economia mista) ou pelos controladores (o Estado, no caso de sociedade de economia mista).

No entanto, os Administradores indicados ou eleitos pelo Estado subordinam-se não só às regras da Lei $n^{0}$ 6.404/76 como também às normas de Direito Público, que regulam a responsabilidade dos agentes públicos. Vale salientar que se incluem na categoria de "agentes administrativos", espécie do gênero “agentes públicos”, “os dirigentes de empresas estatais” (não os seus empregados) como representantes da Administração Indireta

\footnotetext{
${ }^{130}$ EIZIRIK, Nelson, 2011b, p. 297.

131 VENANCIO FILHO, Alberto in PEDREIRA, José Luiz Bulhões; FILHO, Alfredo Lamy, Direito das Companhias, Volume II, Rio de Janeiro: Editora Forense, 2009, p. 1.916.
} 
do Estado, os quais, nomeados ou eleitos, passam a ter vinculação funcional com órgãos públicos da Administração direta, controladores da entidade ${ }^{132}$.

Apesar de sua estrutura, as sociedades de economia mista não estão sujeitas somente ao regime jurídico de natureza privada, uma vez que se submetem em diversos aspectos, às regras de direito público, basicamente pelo propósito de alcançar os objetivos que justificaram a sua criação.

Desta forma, a sociedade de economia mista tem natureza jurídica de pessoa jurídica sui generis, pois é integrante da Administração Indireta do Estado, sujeita aos controles do Poder Legislativo com o auxílio do Tribunal de Contas e cujos administradores, nomeados por ato administrativo, são agentes público ${ }^{133}$.

\subsection{Interesse Público}

Conforme já mencionado acima, o artigo 238 da Lei nº 6.404/76 estabelece que a pessoa jurídica que controla a companhia de economia mista tem os deveres e responsabilidades do acionista controlador além de equiparar a pessoa jurídica que controla a sociedade de economia tem os deveres e responsabilidades do acionista controlador (artigo 116 e 117), mas poderá orientar as atividades da companhia de modo a atender ao interesse público que justificou a sua criação.

Na parte final deste dispositivo é empregado o termo "mas poderá" que, de modo dubitativo, dá a entender que nem sempre o acionista controlador, nas sociedades de economia mista, precisará adotar tal orientação de atender ao interesse público. Mas, na verdade, o objetivo da Lei consiste em reconhecer que as sociedades de economia mista como uma entidade de direito privado - e, portanto, sociedades mercantis que são -,

\footnotetext{
132 VENANCIO FILHO, Alberto in PEDREIRA, José Luiz Bulhões; FILHO, Alfredo Lamy. 2009b. p. 1.916.

${ }^{133}$ EIZIRIK, Nelson. A Lei das S/A Comentada. Volume III - Arts. 189 a 300. São Paulo: Editora Quartier Latin, 2011, p. 312.
} 
devem defender os interesses privados dos acionistas, levando em consideração o interesse público que justificou a sua criação ${ }^{134}$.

Nesse sentido leciona Fran Martins:

"E justamente, como sociedades mercantis que são, as companhias de economia mista devem atender aos interesses particulares dos acionistas mas devem, igualmente, levar em conta o interesse público que justificou a sua criação. Esse fato não constitui uma simples faculdade, como declara a lei, ao usar as palavras "mas poderá" e sim um dever, visto como, para autorizar a criação da sociedade de economia mista, deve o Estado possuir razões de interesse geral que necessita preservar.” 135

E ainda conclui a respeito Fran Martins:

"Se houve, como de fato deve ter havido, um interesse público que justificou a criação da companhia de economia mista, o acionista controlador, ao contrário da faculdade que lhe dá a lei, tem o dever de orientar as atividades da companhia para atender a esse interesse, pois do contrário não se justificaria a sua criação."136

Ainda que apresente uma estrutura jurídica de direito privado, a sociedade de economia mista é necessariamente constituída para alcançar objetivos de interesse público disciplinados na lei que a instituiu ${ }^{137}$. Há por isso um debate acerca da definição de interesse público, que consiste no fato de alguns entendem que seriam incompatíveis as expressões "deveres e responsabilidades do acionista controlador" e "interesse público" dispostas no artigo 238, mas maior parte da doutrina entende que uma vez que o interesse público culminou na criação da sociedade de economia mista, o acionista privado que dela quis participar teve conhecimento das atividades que a companhia iria desempenhar e do interesse público que deverá

\footnotetext{
${ }^{134}$ MARTINS, Fran. Comentários à lei das sociedades anônimas; lei n. ${ }^{\circ} 6.404$, de 15 de dezembro de 1976, volume 3: artigos 206 a 300. Rio de Janeiro, Forense, 1978. P 214.

${ }^{135}$ Ibid. p 215.

${ }^{136}$ Ibid..

${ }^{137}$ EIZIRIK, Nelson,2011b, p. 312.
} 
atender, sendo esta a razão pela qual justificou a sua criação, portanto, não havendo incompatibilidade entre os dois termos do artigo ${ }^{138}$.

O interesse público constitui fator crucial para reconhecimento da caracterização de uma sociedade de economia mista, isto é, não basta apenas que o Estado configure como o acionista controlador de tais companhias, é necessário, além disso, que o interesse público esteja presente permanentemente nos objetivos decorrentes da atividade econômica desempenhada por tal sociedade, que resulta em uma consequente intervenção do Estado no domínio econômico, fazendo-se necessária, portanto, a autorização legal. Neste sentido leciona Gilberto Bercovici:

"O que caracteriza a sociedade de economia mista não é apena a presença majoritária do Estado no seu capital acionário. Uma participação majoritária estatal que fosse transitória ou eventual não modificaria o objeto ou os fins de uma sociedade comum. A sociedade de economia mista é uma estrutura de direito privado (uma sociedade anônima) vinculada de modo permanente a objetivos de interesse publico. Por isto a autorização para sua criação deve ser efetuada por lei. Sem a base legal que a cria, a sociedade de economia mista não passaria de uma sociedade anônima comum, com participação acionária estatal." ${ }^{\text {"139 }}$

No direito administrativo, a expressão "interesse público" tem o sentido de interesse motivador da ação do Estado, encontrando apoio no interesse particular de cada indivíduo, e cabendo ao acionista controlador orientar as atividades da companhia para que os fins sociais sejam atendidos, agindo no interesse coletivo de todos os cidadãos ${ }^{140}$.

Considerando a presença de acionistas privados que nas sociedades de economia mista foram chamados a realizarem investimentos, o Estado como controlador da sociedade de economia mista, além de perseguir o

\footnotetext{
${ }^{138}$ VENANCIO FILHO, Alberto in PEDREIRA, José Luiz Bulhões; FILHO, Alfredo Lamy. 2009b, p. 1.915.

${ }^{139}$ BERCOVICI, Gilberto. Natureza Jurídica de Sociedade Anônima Estatal. Revista de Direito Mercantil. vol 153/154. São Paulo: Malheiros, jan-jul. 2010. p.301)

${ }^{140}$ VENANCIO FILHO, Alberto in PEDREIRA, José Luiz Bulhões; FILHO, Alfredo Lamy. Op.cit, p. 1.915.
} 
interesse público, deve buscar o escopo lucrativo, comum a toda e qualquer companhia $^{141}$.

Neste sentido leciona Eros Grau:

"Vê-se, destarte, que a produção de lucros pelas empresas sob controle do Estado é direta e expressamente admitida em nosso direito positivo. Ainda que não sejam elas constituídas para produzir lucros, esse - a lucratividade delas - é efeito decorrente de sua própria existência." ${ }^{142}$

Na sociedade de economia mista, o Estado perseguirá objetivos de interesse público, podendo orientá-la legitimamente para o seu atendimento, mesmo em detrimento dos interesses dos acionistas minoritários privados, hipótese em que não se caracterizará o abuso do poder de controle. Entretanto, caso o Estado pratique atos de forma que oriente a sociedade de economia mista a agir fora dos limites do seu objeto ou contrariando o seu interesse social, estará, sujeito às consequências da prática de abuso de poder de controle como qualquer acionista controlador privado ${ }^{143}$.

O serviço público deve atender ao princípio da supremacia do interesse público, que se subdivide em interesse público primário ou secundário, definidos como o interesse da coletividade e o interesse dos aparelhos do Estado, respectivamente. A sociedade de economia mista que for utilizada para o atendimento de interesses secundários, ou seja, de interesses dos aparelhos do Estado e de seus agentes, caracterizará o abuso de poder do controlador ${ }^{144}$.

Nesse sentido leciona Modesto Carvalhosa:

"Aí reside o limite do uso ou abuso do controle por parte do Poder Público. A sociedade de economia mista voltada para si mesma, por representar os interesses corporativos dos aparelhos do Estado que a contratou, configura desvio de finalidade. Nesse caso, ocorre desvio de poder, figura típica do direito público e,

\footnotetext{
${ }^{141}$ EIZIRIK, Nelson. 2011b, p. 313.

${ }^{142}$ GRAU, Eros Roberto. Op. cit., p. 55.

${ }^{143}$ EIZIRIK, Nelson. Op.cit., p. 314.

144 CARVALHOSA, Modesto.Comentários à Lei de Sociedades Anônimas, $4^{\circ}$ Volume Tomo IArts. 206 a 242. São Paulo: Saraiva, 2011. P. 438.
} 
portanto, inteiramente aplicável ao ente público controlador da sociedade de economia mista. E o desvio de finalidade caracteriza-se quando o controlador, embora observando a estrutura da sociedade de economia mista, desvirtua as finalidades de atendimento do interesse coletivo para a qual foi criada.”

Portanto, verifica-se que as sociedades de economia mista têm por escopo o interesse público, elemento crucial para sua caracterização, mas por ostentarem natureza de sociedades mercantis, devem defender também os interesses privados dos acionistas ${ }^{145}$.

${ }^{145}$ MARTINS, Fran. Op. cit.. p 214. 


\section{CAPÍTULO 4. POSICIONAMENTOS CVM}

Neste Capítulo serão expostos casos julgados no âmbito da Comissão de Valores Mobiliários - CVM, que versam tanto sobre o dever de diligência dos Administradores, quanto sobre o interesse público que rege as sociedades de economia mista, que evidenciam o posicionamento da Comissão de Valores Mobiliários - CVM a respeito.

\subsection{Caso Sadia S.A. (PAS CVM no 18/08) - Dever de Diligência}

A Comissão de Valores Mobiliários - CVM já teve a oportunidade de julgar casos envolvendo o dever de diligência dos Administradores. Estas decisões tornaram-se referência como paradigma em outros casos e impactaram a todos que atuam no mercado de ações ${ }^{146}$.

Cumpre $\operatorname{citar}^{147}$ o Processo Administrativo Sancionador CVM ${ }^{\circ}$ $18 / 08^{148}$, que tratou do descumprimento de esperado dever de diligência por parte dos administradores da Sadia S.A. em razão de operações com derivativos realizadas pela companhia. Este descumprimento foi constatado a partir da divulgação de fato relevante, em 25 de setembro de 2008, em que se informava acerca da decisão da companhia de liquidar antecipadamente essas operações, ocasionando perdas de cerca de $\mathrm{R} \$ 760.000 .000,00$ (setecentos e sessenta milhões de reais).

A acusação entendeu ter havido violação ao dever de se informar, tanto por parte dos membros do Comitê Financeiro, quanto em relação àqueles pertencentes ao Comitê de Auditoria, pois não obtiveram no exercício de seu mandato as informações necessárias para exercerem adequadamente as suas respectivas funções.

\footnotetext{
${ }^{146}$ QUATTRINI, Larissa Teixeira. Op. cit., p. 174.

${ }^{147}$ Ibid. p. 196.

148 CVM, Processo Administrativo Sancionador CVM no 18/08, Diretor Alexsandro Broedel Lopes, Rio de Janeiro, 14 de dezembro de 2010.
} 
Nesse sentido, o dever de os administradores buscarem informações e exercerem suas funções de modo esclarecido é ínsito ao próprio dever de diligência que exige que os administradores se informem adequadamente acerca da situação da companhia e sobre a forma com que ela está sendo conduzida, além de seus produtos e principais serviços.

No caso de órgãos técnicos ou consultivos criados para integrar a estrutura societária da companhia, aplica-se o disposto no artigo 160 da Lei $n^{\circ}$ 6.404/76, que lhes impõe o cumprimento do dever de diligência. $O$ Diretor Relator do caso, Alexsandro Broedel Lopes, em seu voto, citou interessante doutrina internacional que vale ser aqui transcrita:

\begin{abstract}
“A administração pode ser desonesta - passando por cima dos controles, ignorando ou ocultando comunicações dos subordinados e intencionalmente adulterando resultados para encobrir as pistas - mas um conselho forte e ativo irá identificar e corrigir esse tipo de situação. O conselho pode ser particularmente eficaz quando canais de comunicação sólidos e funções competentes de auditoria interna, legal e financeiras estiverem presentes". ${ }^{49}$
\end{abstract}

O Diretor Relator concluiu pelo descumprimento do dever de diligência - particularmente aos deveres de monitorar e de se informar por parte dos conselheiros ao negligenciarem as falhas ocorridas no desenho do sistema de controle internos da Sadia S.A. e, por conseguinte, deixarem de observar os atos praticados pela Diretoria Financeira e as operações de derivativos realizadas. Entendeu ainda o Relator que a especialização técnica dos conselheiros haveria de ser considerada, observando-se, contudo, a responsabilidade colegiada (exceto quando da consignação de discordância sobre atos praticados).

O Relator afirmou ainda que o padrão de conduta há de ser ainda mais elevado na atuação dos conselheiros membros dos Comitês Financeiro e de Auditoria que possuem uma função específica no Conselho de Administração. Conclui o Relator que tais conselheiros especializados

\footnotetext{
${ }^{149}$ BRAIOTTA, Louis. The Audit Committee Handbook. 5. Ed. New Jersey: Wiley, p. 239 apud item 51 do voto do Relator, CVM, Processo Administrativo Sancionador CVM no 18/08, Diretor Alexsandro Broedel Lopes, Rio de Janeiro, 14 de dezembro de 2010.
} 
descumpriram também o dever de investigar - corolário do dever de diligência, que impõe aos administradores o dever de analisar criticamente as informações que lhes são fornecidas, bem como de apurar se merecem complemento.

Por fim, o Colegiado da Comissão de Valores Mobiliários decidiu, por maioria de votos, pela absolvição de quatro conselheiros, dois pela inexistência nos autos de elementos que permitissem a sua responsabilização e outros dois em razão de inexistirem indicativos da atuação específica. Além disso, por terem assumido o Conselho de Administração apenas em abril de 2008, não teriam ocupado as funções por tempo razoável para que pudessem tomar as providências esperadas de um administrador. Entretanto, acerca do descumprimento do dever de diligência, decidiu pela aplicação de multa de $\mathrm{R} \$$ 400.000,00 (quatrocentos mil reais) aos conselheiros que era também membros do Comitê Financeiro ou do Comitê de Auditoria da Sadia S.A. e com relação aos demais conselheiros - no âmbito da aplicação da multa pecuniária - foi aplicada multa de $\mathrm{R}$ \$ 200.000,00 (duzentos mil reais) e ainda condenado o exDiretor Financeiro da Sadia S.A. à pena de inabilitação temporária por 3 (três) anos para o exercício de cargo de administrador de companhia aberta.

\subsection{Caso Centrais Elétricas Brasileiras S.A. - Eletrobras (PAS CVM nº RJ2013/6635) - Interesse Público}

Este presente Processo Administrativo Sancionador CVM $\mathrm{n}^{\mathrm{o}}$ RJ2013/6635 ${ }^{150}$ foi instaurado pela Superintendência de Relações com Empresas contra União Federal, a fim de apurar uma suposta violação do artigo $115, \S 1^{\circ}$, da Lei $n^{o} 6.404 / 76^{151}$, que trata do impedimento de voto por

\footnotetext{
${ }^{150}$ CVM, Processo Administrativo Sancionador CVM n ${ }^{\circ}$ RJ2013/6635, Diretora Luciana Dias, Rio de Janeiro, 26 de maio de 2015.

${ }^{151}$ De acordo com o artigo $115, \S 1^{\circ}$ da Lei $\mathrm{n}^{\circ}$ 6.404/76, “o acionista não poderá votar nas deliberações da assembleia geral relativas ao laudo de avaliação de bens com que concorrer para a formação do capital social e à aprovação de suas contas como administrador, nem em quaisquer outras que puderem beneficiá-lo de modo particular, ou em que tiver interesse conflitante com o da companhia"
} 
conflito de interesses, pelo fato de a União ter votado em assembleia geral extraordinária da sua controlada Centrais Elétricas Brasileiras S.A. Eletrobras, realizada em 3 de dezembro de 2012.

$\mathrm{Na}$ referida assembleia geral extraordinária, a União votou favoravelmente à renovação de contratos de concessão de geração e transmissão de energia elétrica celebrados entre ela própria, enquanto concedente de um lado, e sociedades controladas da Eletrobras enquanto concessionárias, de outro.

Na hipótese, como a Eletrobras é sociedade de economia mista, o artigo 238 da Lei no 6.404/76 - que trata do “interesse público” configurou-se de grande relevância em torno da discussão do caso concreto.

Questionada, a União sustentou que seu voto estaria em linha com esse dispositivo, enquanto que os acionistas minoritários alegaram que a conduta da União só estaria abarcada pelo artigo 238 da Lei n ${ }^{\circ}$ 6.404/76 caso o referido “interesse público” constasse da lei de criação da Eletrobras, a saber, a Lei $\mathrm{n}^{\mathrm{o}}$ 3.890-A, de 25 de abril de 1961. O argumento dos acionistas minoritários fundamentou-se no fato de que assegurar a modicidade tarifária não consta como um dos interesses públicos que justificaram a criação da Eletrobras, cujas atividades não poderiam ser orientadas pela União para a consecução desse objetivo.

A Superintendência de Relações com Empresas concluiu que a conduta da União deveria ser enquadrada na exceção do artigo 238 da Lei $n^{\circ} 6.404 / 76$, uma vez que a persecução da modicidade tarifária concorreria paralelamente à obtenção de um benefício eminentemente financeiro e exclusivo da União. Desta forma, a Superintendência de Relações com Empresas entendeu que a satisfação daquele interesse público relacionado à política energética e à definição das tarifas não poderia ser invocada pela União como uma exceção ao impedimento de voto por conflito de interesses e acusou a União de violar o artigo 115 , $§ 1^{\circ}$ da Lei ${ }^{\circ}$ 6.404/76. 
Em sede de recente julgamento pelo Colegiado da Comissão de Valores Mobiliários, em 26 de maio de 2015, Relatora a Diretora Luciana Dias abordou, em seu voto, o “interesse público” das sociedades de economia mista.

Para a Relatora, o artigo 238 não parece afastar os deveres e responsabilidades atribuídos a qualquer acionista controlador ou modificar as regras gerais a que se sujeita qualquer companhia aberta.

Pelo contrário, entende Luciana Dias que referido artigo reafirma esses deveres e, em caráter excepcional, apenas estabelece que as atividades da companhia poderão ser conduzidas pelo controlador (e exclusivamente pelo controlador) de modo a atender o interesse público que justificou a sua criação.

Para a Relatora, na verdade, a principal consequência do artigo 238 não diz respeito a um regime de exceção justificado pelo interesse público, mas, sim, a confirmação de que o regime jurídico societário, construído e desenvolvido ao longo do tempo como um parâmetro de convívio para a proteção dos interesses típicos de uma coletividade dos sócios, permanece incólume e aplicável à disciplina das situações de conflito que podem opor os acionistas, sejam eles públicos ou privados. O propósito do artigo 238 seria o de impedir que se questionem as decisões do controlador quando elas visam a promover o interesse público primário que justificou a criação da companhia.

\section{Luciana Dias leciona:}

“(...) a referência a um interesse público específico e limitado, qual seja, aquele que justificou a criação da sociedade de economia mista, denota a preocupação do legislador de limitar a utilização heterodoxa da companhia ao conteúdo de uma norma específica, conferindo previsibilidade e segurança jurídica aos investidores em geral. A parte final do artigo 238 somente se explica pela intenção do legislador de limitar o interesse público que pode mover o Estado. Isto porque seria desnecessário dizer ao Estado que deve agir orientado pelo interesse público - é premissa de toda ação do Estado se pautar por algum interesse público, de grande ou reduzida extensão, em especial, quando o Estado abre uma exceção à 
regra de livre iniciativa e resolve exercer uma atividade econômica por meio de uma empresa pública ou de economia mista ${ }^{152,}$.

A Diretora Relatora ainda ensina em seu voto:

“O Estado, assim, não está autorizado a conduzir os negócios da companhia com base em qualquer interesse público, mas tão somente aquele enunciado na lei que criou a respectiva estatal. (...) Em uma sociedade de economia mista com acionistas privados, as salvaguardas da Lei ${ }^{0}$ 6.404, de 1976, não devem ser vistas como óbices à concretização do interesse público que justificou a criação da companhia, mas como balizas que limitam, condicionam e dão forma à própria satisfação desse interesse. São regras do jogo, a que o Estado aderiu e se submeteu espontânea e livremente quando confiou às companhias a realização de finalidades públicas ${ }^{153}$ ”.

A partir do voto da Diretora Relatora Luciana Dias, o Colegiado da Comissão de Valores Mobiliários - CVM - decidiu, de forma unânime, pela condenação da União à penalidade de $\mathrm{R} \$$ 500.000,00 (quinhentos mil reais), por infringir o disposto no artigo $115, \S 1^{\circ}$, da Lei $n^{\circ} 6.404 / 76$, figurando conflito de interesses ao votar na assembleia geral extraordinária pela renovação das concessões de distribuição e transmissão de energia elétrica de companhias controladas pela Eletrobras.

Neste processo, o valor da multa - o máximo para casos como este -, é o menos importante, uma vez que a União pagará para si mesma. O relevante desta decisão unânime é ter criado um precedente para a atuação do governo no controle de estatais com capital aberto.

\footnotetext{
${ }^{152}$ CVM, Processo Administrativo Sancionador CVM n ${ }^{\circ}$ RJ2013/6635, Diretora Luciana Dias, Rio de Janeiro, 26 de maio de 2015.

${ }^{153}$ Ibid.
} 


\section{CAPÍTULO 5. CORRELAÇÃO ENTRE O DEVER DE DILIGÊNCIA DOS ADMINISTRADORES E O INTERESSE PÚBLICO DAS SOCIEDADES DE ECONOMIA MISTA}

Conforme já exposto no presente trabalho monográfico, acerca das sociedades de economia mista, observamos que o Estado ao constituir uma empresa estatal, visa à realização de atividade econômica ou serviço público por ele outorgados a fim de atender objetivo de política pública, ou porque o capital privado não tem condições ou interesse em produzi-lo, ou ainda, porque se decidiu excluir aquela atividade produtiva da esfera privada.

A sociedade de economia mista, cuja criação é autorizada por lei, tem o propósito de atender ao interesse público, com a participação ativa do Poder Público na vida e realização da empresa. O interesse público configura verdadeiro dever e não mera faculdade, pois do contrário não haveria razão para o Estado integrar o capital social da sociedade de economia mista, muito menos de ser o seu acionista controlador, hipótese em que, portanto, a sociedade não deveria ser de economia mista e, sim, de capital privado.

Como vimos, o dever de diligência tem enorme relevância para o direito societário brasileiro, pois se trata do norte de atuação dos Administradores, o que significa que a Lei estabeleceu um padrão de conduta base que deverá ser seguido. Esse dever desdobra-se em outros, tais como os deveres de se qualificar para o exercício da função de administrador, de bem administrar, de se informar, de investigar e de vigiar.

O dever de diligência é mais que um dever, constitui um princípio geral de direito que anda lado a lado com o administrador no âmbito da gestão de uma companhia, configurando um dever cuja orientação flexível 
deve ser aplicada cautelosamente caso a caso, levando em consideração a respectiva função de cada administrador.

Assim, requer-se mais do que um esforço exigível para o cumprimento de uma determinada obrigação, a conduta do administrador deve-se pautar também pela dedicação, atenção, zelo e cuidado para uma atuação competente e profissional ${ }^{154}$.

A correlação entre o dever de diligência dos administradores e o interesse público das sociedades de economia mista se dá partindo da premissa de que a criação destas companhias mistas apenas se justifica quando existe um interesse público a ser atendido. Diante da primazia do interesse público há uma responsabilidade do Estado frente a todo o país, o que não ocorre numa sociedade de capital privado, pois esta visa o atendimento de fins particulares.

Ora, se o que culmina a criação de uma sociedade de economia mista é a consecução de fins de interesse público, que se refere à coletividade de todos os cidadãos, há de se constatar que aos administradores das sociedades de economia mista exige-se ainda mais rigor no cumprimento do dever de diligência.

Quando se tem em jogo um interesse superior, pelo qual teve de se recorrer à intervenção do Estado no domínio econômico que, atuando como empresário, presta um serviço de relevante interesse coletivo, do qual uma nação inteira necessita e depende - como, por exemplo, a energia elétrica, no caso da Eletrobras, ou de combustíveis, no caso da Petrobras - nada mais lúcido do que, diante de tamanha responsabilidade, exigir-se um padrão de conduta ainda mais elevado no que tange ao cumprimento do dever de diligência por parte dos Administradores das sociedades de economia mista.

Porém, infelizmente, o que verificamos na prática, como diz o Professor Francisco Müssnich, é o Estado querendo ser “jogador do time e

\footnotetext{
${ }^{154}$ PARENTE, Flávia. Op. cit., p. 42.
} 
árbitro do jogo ao mesmo tempo", atribuindo-lhe objetivos complementares, não necessariamente vinculados aos que inspiraram a sua instituição, como praticar preços inferiores aos de mercado, gerar empregos, ou promover o desenvolvimento de determinada região. Verifica-se, na verdade, a utilização da empresa estatal para desenvolver políticas clientelísticas de Governo, que podem caracterizar a adoção de decisões cuja finalidade não seja o interesse da sociedade de economia mista e visem a causar prejuízos aos acionistas minoritários e investidores, consoante o disposto no artigo 117, §1º, alínea “c” da Lei nº 6.404/76 ${ }^{155} 156$.

155 De acordo com o artigo 117, §1º alínea “c” da Lei $n^{\circ}$ 6.404/76, “O acionista controlador responde pelos danos causados por atos praticados com abuso de poder. § $1^{\circ}$ São modalidades de exercício abusivo de poder: c) promover alteração estatutária, emissão de valores mobiliários ou adoção de políticas ou decisões que não tenham por fim o interesse da companhia e visem a causar prejuízo a acionistas minoritários, aos que trabalham na empresa ou aos investidores em valores mobiliários emitidos pela companhia”.

${ }^{156}$ EIZIRIK, Nelson. 2011b, p. 315. 


\section{Conclusão}

Diante do acima exposto, verificamos que o papel dos Administradores numa companhia é de extrema importância, uma vez que dentro de suas respectivas esferas de competência, conduzem os negócios sociais e representam a companhia, tendo imensa responsabilidade no sucesso ou no insucesso da empresa.

Devido a essa relevância o legislador procurou estabelecer deveres para os Administradores, mesclando intencionalmente princípios e comportamentos em suas descrições como uma forma de preocupação em prover um guia seguro de orientação à atuação destes Administradores.

E, dentre estes deveres, o dever de diligência se destaca como a regra suprema do norte de atuação dos Administradores, caracterizando-se como um padrão geral de conduta, com uma orientação flexível, cuja aplicabilidade deve ser verificada caso a caso.

Como também acima demonstrado, a criação de uma sociedade de economia mista apenas se justifica quando existe um interesse público a ser atendido e que deve constar da sua lei de criação.

Assim, pelo fato de as sociedades de economia mista terem a responsabilidade de atender a um interesse público, prestando um serviço de relevante interesse coletivo do qual todos os cidadãos necessitam e dependem, deve ser exigido de seus Administradores o mais elevado standard de cumprimento ao dever de diligência.

Vale ressaltar, que a correlação entre o dever de diligência e o interesse público das sociedades de economia mista não significa de forma alguma dar menos liberdade aos seus Administradores e nem inibir as suas atuações. Desta forma, as decisões tomadas de boa-fé pelos Administradores das sociedades de economia mista, em observância ao cumprimento do dever de diligência e aos demais deveres que deste se 
desdobram, mas que venham a se revelar inadequadas ou mal sucedidas, serão amparadas pela business judgment rule, para que se possa encorajar estes Administradores a servirem às companhias, de modo equilibrado e alinhado com os deveres que lhes são impostos, porém, assumindo os riscos inerentes à atividade empresarial e que podem vir a ser benéficos para a companhia. 


\section{Referências Bibliográficas}

BERCOVICI, Gilberto. Natureza Jurídica de Sociedade Anônima Estatal. Revista de Direito Mercantil. vol 153/154. São Paulo: Malheiros, jan-jul. 2010.

BRAIOTTA, Louis. The Audit Committee Handbook. 5. Ed. New Jersey: Wiley.

CASTELLO BRANCO, Adriano, O Conselho de Administração nas Sociedades Anônimas, Rio de Janeiro: Forense Universitária, 2007.

CARVALHO DE MENDONÇA, José Xavier. Tratado de Direito Comercial Brasileiro, Volume IV, Livro II Dos Comerciantes e seus Auxiliares, Parte III - Das Sociedades Comerciais, $5^{a}$ edição. São Paulo: Livraria Freitas Bastos S.A., 1954.

CARVALHOSA, Modesto. Comentários à Lei das Sociedades Anônimas. $3^{\circ}$ Volume. Artigos 138 a 205. São Paulo: Saraiva, 2009. Pg. 175.

.Comentários à Lei de Sociedades Anônimas, $4^{\circ}$ Volume Tomo I - Arts. 206 a 242. São Paulo: Saraiva, 2011.

COELHO, Fábio Ulhoa. Curso de Direito Comercial, volume 2: Direito de Empresa. São Paulo: Saraiva, 2010.

EIZIRIK, Nelson. A Lei das S/A Comentada. Volume II - Arts. 121 a 188. São Paulo: Editora Quartier Latin, 2011.

. A Lei das S/A Comentada. Volume III - Arts. 189 a 300.

São Paulo: Editora Quartier Latin, 2011. 
GRAU, Eros Roberto. Lucratividade e Função Social nas Empresas sob Controle do Estado. Revista de Direito Mercantil. vol 55. São Paulo: Malheiros.

INSTITUTO BRASILEIRO DE GOVERNANÇA CORPORATIVA. Código das Melhores Práticas de Governança Corporativa, $4^{a}$ edição. São Paulo, SP: IBGC, 2009. Disponível em http://www.ibgc.org.br. Acesso em 23 de maio de 2015.

MARTINS, Fran. Comentários à lei das sociedades anônimas; lei $n^{\circ}$ 6.404, de 15 de dezembro de 1976, volume 3: artigos 206 a 300. Rio de Janeiro, Forense, 1978.

PARENTE, Flavia. O Dever de Diligência dos Administradores de Sociedades Anônimas. Rio de Janeiro: Renovar, 2005.

PEDREIRA, José Luiz Bulhões; FILHO, Alfredo Lamy, Direito das Companhias, Volume I, Rio de Janeiro: Editora Forense, 2009.

; FILHO, Alfredo Lamy, Direito das

Companhias, Volume II, Rio de Janeiro: Editora Forense, 2009.

RIBEIRO, Renato Ventura. Dever de Diligência dos Administradores de Sociedades. São Paulo: Quarter Latin, 2006.

QUATTRINI, Larissa Teixeira. Os Deveres dos Administradores de Sociedades Anônimas Abertas: Estudo de Casos. São Paulo: Saraiva, 2014.

SILVA, Alexandre Couto. Direito Societário: Estudos sobre a Lei de Sociedade por Ações. São Paulo: Saraiva, 2013.

TEIXEIRA, Egberto Lacerda; GUERREIRO, José Alexandre Tavares. Das Sociedades Anônimas no Direito Brasileiro, Volume 2. São Paulo: Bushatsky, 1979. 
VIVANTE, Cesare, Instituições de Direito Comercial; Tradução e notas de Ricardo Rodrigues Gama, Campinas - SP: LZN Editora, 2003.

WALD, Arnoldo. Do Regime Legal do Conselho de Administração e da Liberdade de Votos dos seus Componentes. Revista da Associação dos Juízes do Rio Grande do Sul - Ajuris, n. 43. 